\title{
Antimicrobial Resistance in Escherichia coli
}

\section{LAURENT POIREL, ${ }^{1,2,3}$ JEAN-YVES MADEC, ${ }^{4}$ AGNESE LUPO, ${ }^{4}$ ANNE-KATHRIN SCHINK, ${ }^{5}$ NICOLAS KIEFFER, ${ }^{1}$ PATRICE NORDMANN, ${ }^{1,2,3}$ and STEFAN SCHWARZ ${ }^{5}$}

${ }^{1}$ Emerging Antibiotic Resistance Unit, Medical and Molecular Microbiology, Department of Medicine, University of Fribourg, Fribourg, Switzerland; ${ }^{2}$ French INSERM European Unit, University of Fribourg (LEA-IAME), Fribourg, Switzerland; ${ }^{3}$ National Reference Center for Emerging Antibiotic Resistance (NARA), Fribourg, Switzerland; ${ }^{4}$ Université de Lyon - Agence Nationale de Sécurité Sanitaire (ANSES), Unité Antibiorésistance et Virulence Bactériennes, Lyon, France; ${ }^{5}$ Institute of Microbiology and Epizootics, Centre of Infection Medicine, Department of Veterinary Medicine, Freie Universität Berlin, Berlin, Germany

ABSTRACT Multidrug resistance in Escherichia coli has become a worrying issue that is increasingly observed in human but also in veterinary medicine worldwide. $E$. coli is intrinsically susceptible to almost all clinically relevant antimicrobial agents, but this bacterial species has a great capacity to accumulate resistance genes, mostly through horizontal gene transfer. The most problematic mechanisms in E. coli correspond to the acquisition of genes coding for extended-spectrum $\beta$-lactamases (conferring resistance to broad-spectrum cephalosporins), carbapenemases (conferring resistance to carbapenems), 16S rRNA methylases (conferring pan-resistance to aminoglycosides), plasmid-mediated quinolone resistance (PMQR) genes (conferring resistance to [fluoro]quinolones), and $\mathrm{mcr}$ genes (conferring resistance to polymyxins). Although the spread of carbapenemase genes has been mainly recognized in the human sector but poorly recognized in animals, colistin resistance in $E$. coli seems rather to be related to the use of colistin in veterinary medicine on a global scale. For the other resistance traits, their cross-transfer between the human and animal sectors still remains controversial even though genomic investigations indicate that extended-spectrum $\beta$-lactamase producers encountered in animals are distinct from those affecting humans. In addition, $E$. coli of animal origin often also show resistances to other-mostly older-antimicrobial agents, including tetracyclines, phenicols, sulfonamides, trimethoprim, and fosfomycin. Plasmids, especially multiresistance plasmids, but also other mobile genetic elements, such as transposons and gene cassettes in class 1 and class 2 integrons, seem to play a major role in the dissemination of resistance genes. Of note, coselection and persistence of resistances to critically important antimicrobial agents in human medicine also occurs through the massive use of antimicrobial agents in veterinary medicine, such as tetracyclines or sulfonamides, as long as all those determinants are located on the same genetic elements.

\section{INTRODUCTION}

Escherichia coli is a bacterium with a special place in the microbiological world since it can cause severe infections in humans and animals but also represents a significant part of the autochthonous microbiota of the different hosts. Of major concern is a possible transmission of virulent and/or resistant E. coli between animals and humans through numerous pathways, such as direct contact, contact with animal excretions, or via the food chain. E. coli also represents a major reservoir of resistance genes that may be responsible for treatment

Correspondence: Laurent Poirel, laurent.poirel@unifr.ch 
failures in both human and veterinary medicine. An increasing number of resistance genes has been identified in E. coli isolates during the last decades, and many of these resistance genes were acquired by horizontal gene transfer. In the enterobacterial gene pool, E. coli acts as a donor and as a recipient of resistance genes and thereby can acquire resistance genes from other bacteria but can also pass on its resistance genes to other bacteria. In general, antimicrobial resistance in E. coli is considered one of the major challenges in both humans and animals at a worldwide scale and needs to be considered as a real public health concern.

This chapter gives an update of antimicrobial resistance in E. coli of animal origin by focusing on resistance to those classes of antimicrobial agents mainly used in veterinary medicine and to which E. coli isolates of animal origin are known to exhibit resistance.

\section{E. COLI IN ANIMALS: A PATHOGENIC AND A COMMENSAL BACTERIUM}

"Colibacillosis" is a general term for a disease caused by the bacterium E. coli, which normally resides in the lower intestines of most warm-blooded mammals. Hence, E. coli is a versatile microorganism with a number of pathogenic isolates prone to cause intestinal and extra-intestinal infections, while most others are harmless for their host and refer to commensalism. The pathogenic E. coli isolates can be classified into different pathotypes, or pathovars, where each pathotype causes a different disease (1). The intestinal pathogenic E. coli pathovars are responsible for disorders in the gut ranging from mild diarrhea to severe colitis, while the extra-intestinal pathogenic E. coli pathovars are mostly asymptomatic inhabitants of the intestinal tract that cause extra-intestinal diseases after migrating to other parts of the body, such as the urinary tract or the blood stream (2). Animal diseases due to E. coli can also be caused by E. coli isolates originating from the environmental reservoir or other infected individuals. Pathogenic and nonpathogenic $E$. coli differ by the acquisition or loss of virulence-associated traits associated with E. coli pathogenicity. The number of genes present in the E. coli genome varies from 4,000 to 5,000 genes, with approximately 3,000 genes shared by the different isolates, whereas the others mostly correspond to colonization or virulence determinants. Advanced insights in the genomic plasticity of $E$. coli have been possible by the use of whole-genome sequencing, providing a better understanding of the core and accessory genomes of pathogenic and commensal E. coli isolates (ㄱ).
In animals, E. coli is one of the leading causes of diarrhea, together with other pathogens such as rotavirus, coronavirus, Cryptosporidium parvum, or a combination of these (4). These enterotoxigenic E. coli (ETEC) strains bind and colonize the intestinal epithelium through adhesins expressed in the context of fimbriae, such as the F4 (formerly designated K88), F5 (K99), F6 (987P), F17, and F18 fimbriae (ㅁ). ETEC also produces various enterotoxins, of which heat-labile and heat-stable toxins and/or enteroaggregative heat-stable toxin 1 (EAST1) lead to diarrhea. ETEC affects various animal species, mostly young animals, particularly foodproducing animals (piglets, newborn calves, chickens) but also companion animals such as dogs. In livestock, diarrhea is considered one of the major diseases, which can propagate among animals with possibly significant consequences at the herd/flock level. Diarrhea is observed in pigs and calves during the first 3 to 5 days of life and in pigs 3 to 10 days after weaning. The trend toward early weaning in several countries and continents may have played a significant role in the rising occurrence of postweaning diarrhea in the pig sector. As a consequence, lethal ETEC infections in animals can also occur as a result of severe dehydration and electrolyte imbalance.

E. coli infections in animals are not restricted to young individuals but occur in adults as well. As mentioned above, extra-intestinal pathogenic E. coli is responsible for infections of the lower and upper urinary tract, particularly in companion animals $(\underline{6}, \underline{7})$. In poultry, avianpathogenic E. coli causes colibacillosis initiated in the respiratory tract by inhalation of fecal dust before spreading further in the whole body, causing septicemia, pericarditis, and mortality (ㅇ). In dairy cattle, mastitis is a common inflammatory response of the mammary gland, significantly decreasing milk production and causing dramatic economic losses, with E. coli being one of the major causes-together with Staphylococcus aureus, Streptococcus uberis, Streptococcus agalactiae, and Streptococcus dysgalactiae $(9,10)$. In particular, E. coli is responsible for more than $80 \%$ of cases of acute mastitis where the severe clinical signs are induced by the lipopolysaccharide (LPS) as a primary virulence factor followed by the subsequent release of inflammatory mediators $(\underline{11})$. Nonetheless, it is broadly considered that mastitis in dairy cattle due to $E$. coli is neither associated with specific $E$. coli serovars nor involves a common set of virulence factors shared among $E$. coli isolates.

E. coli infections in animals are subjected to various pharmaceutical treatments including antimicrobials. For instance, ampicillin, streptomycin, sulfonamides, 
or oxytetracyclines are commonly used to treat bovine mastitis, but broad-spectrum cephalosporins and fluoroquinolones also have indications through systemic or local administration depending on the severity of the clinical symptoms (12) and the resistance properties of the causative E. coli isolates. Nonetheless, the role of antimicrobials in the treatment of coliform mastitis is becoming more and more open to debate. Recommendations provided for veterinarians refer to the preferable use of first-line antimicrobial agents and avoidance of antimicrobial therapy during the dry-off period of dairy cattle. Global data and trends on the antimicrobial resistance of E. coli in mastitis have been highlighted in several national reports and vary among countries even though relevant comparisons are difficult. To date, the global picture indicates that antimicrobial susceptibility of E. coli in mastitis remains high. In particular, extended-spectrum $\beta$-lactamases (ESBLs) or overexpressed cephalosporinases (AmpCs) produced by E. coli and conferring resistance to broad-spectrum cephalosporins have been sporadically isolated from milk samples (13-16). Those families of antimicrobial agents may also be prescribed in newborns affected by diarrhea. Again, action plans against antimicrobial resistance in the animal sector constantly advise veterinarians to use antimicrobials prudently and emphasize the need to consider all other preventive and therapeutic options and restrict the use of antimicrobial agents to those situations where it is indispensable (17). For instance, strategies to prevent and treat neonatal diarrhea should include not only the prescription of antimicrobials but also good colostrum management practices to ensure adequate passive immunity and appropriate oral or intravenous fluid therapy to compensate for dehydration, acidosis, and electrolyte imbalance (18). Global hygiene procedures at the farm level and vaccinations are also essential measures for improvement in antimicrobial stewardship. In contrast to mastitis, ESBL/AmpC genes have been abundantly reported in E. coli originating from the digestive tract in animals. This includes pathogenic E. coli recovered from diarrheic samples of young animals, yet it remains highly difficult to confirm that a specific E. coli isolate is responsible for the intestinal disease. More importantly, ESBL/AmpC genes have been widely recognized in commensal E. coli isolated from fecal samples of various food-producing and companion animals through selective screenings using cephalosporin-containing media (19-21). High prevalence rates of ESBL/AmpC-producing E. coli were found in certain settings and countries, such as in the veal calves sector in Europe and in broiler production worldwide. In those cases, it more likely reflects the selective impact of the use of antimicrobials-and particularly of broad-spectrum cephalosporins such as ceftiofur-on the commensal E. coli microbiota. In broilers, such a situation has become a point of major concern on a global scale since broad-spectrum cephalosporins are both of critical importance in human medicine and not authorized for use in poultry. In addition to national actions taken, mostly in Europe, to restrict the use of critically important antimicrobial agents in animals, the use of antimicrobial agents as growth promoters has been banned in animals in Europe since 2006, but it is still common practice in most countries. Altogether, since antimicrobial agents have a major impact on the gut microbiota where E. coli resides, multidrug-resistant E. coli, such as ESBL/AmpCproducing E. coli, has become one of the main indicators to estimate the burden of antimicrobial resistance in animals and other sectors in a One Health perspective.

\section{RESISTANCE TO $\beta$-LACTAMS}

There are numerous genes in E. coli of human and animal origin that confer resistance to $\beta$-lactams. Some of them, such as $b l a_{\mathrm{TEM}-1}$, are widespread in E. coli from animals but code only for narrow-spectrum $\beta$-lactamases that can inactivate penicillins and aminopenicillins. However, in recent years, genes that code for ESBLs/AmpCs have emerged in E. coli from humans and animals. Most recently, genes coding for carbapenemases have also been detected occasionally in E. coli of animal origin. Because of the relevance of these latter two groups of $\beta$-lactamases, the following subsections provide more detailed information on ESBLs, AmpCs, and carbapenemases.

\section{Clavulanic-Acid Inhibited Class A ESBLs}

ESBLs belong mostly to class A of the Ambler classification (22) and group 2 be according to the updated functional classification of $\beta$-lactamases by Bush and Jacoby (23). ESBL-producing strains of E. coli are clinically relevant in veterinary medicine since they confer resistance to penicillins, aminopenicillins, and cephalosporins, including the third-generation cephalosporins ceftiofur and cefovecin and the fourth-generation cephalosporin cefquinome, which are approved veterinary drugs. Thus, ESBLs may be the cause of treatment failures and limit the therapeutic options of veterinarians, because they have been identified in increasing numbers in E. coli of food-producing and companion animals worldwide $(24,25)$. ESBL-producing E. coli from animals has been isolated not only from infection sites, but 
also from the feces of healthy individuals (26-29). Moreover, ESBL-producing E. coli has also been detected in wild animals, emphasizing the wide distribution of these resistance determinants (30).

TEM- and SHV-ESBLs were among the first described ESBLs in the 1980s, and they were predominant until 2000. Since then, CTX-M-ESBLs emerged and have been predominantly identified in commensal and pathogenic ESBL-producing E. coli isolates of human and animal origin around the world $(31,32)$. The reason for this shift remains unknown, despite many investigations and surveillance studies. It is difficult to compare prevalence data of ESBL-producing E. coli isolates because several resistance-monitoring programs register the resistance rates for cephalosporins in E. coli isolates of animal origin but do not necessarily confirm whether this resistance is based on ESBL production or another $\beta$-lactamase. Moreover, the molecular identification of ESBL genes in monitoring programs is not systematic. The nonharmonized methodology is also reflected in sampling plans and therefore in the origin of the E. coli isolates, e.g., healthy or diseased animals (33). Nevertheless, the European Food Safety Authority compiled a scientific opinion which states that the prevalence of resistance to cefotaxime in food-producing animals varies by country and animal species. In addition, the ESBL genes $b l a_{\text {CTX-M-1 }}, b l a_{\text {CTX-M-14, }}, b l a_{\text {TEM-52, }}$, and bla $_{\mathrm{SHV}-12}$ were identified as the most common ones along with a wide range of other $b l a_{\mathrm{CTX}-\mathrm{M}}, b l a_{\mathrm{TEM}}$, and bla $_{\mathrm{SHV}}$ variant genes (34) (Table 1).

A large study conducted in Germany analyzed ESBL-producing E. coli isolates collected from diseased

TABLE 1 Examples of acquired ESBL genes in E. coli of animal origin from Europe, the U.S., Latin America, Africa, and Asia

\begin{tabular}{|c|c|c|c|c|}
\hline ESBL gene & Geographical origin & Source & Sequence type(s) & Reference \\
\hline \multirow[t]{10}{*}{ bla $\mathrm{CTX}-\mathrm{M}-1$} & Denmark & Pig & $\begin{array}{l}10,189,206,453,542,744,910,1406,16842739 \\
4048,4052,4053,4056\end{array}$ & $\underline{257}$ \\
\hline & Sweden & Poultry & $57,135,155,219,602,752,1594,1640$ & $\underline{258}$ \\
\hline & Great Britain & Poultry & $4,10,57,88,155,371,1515,1517,1518,1549,1550$ & $\underline{259}$ \\
\hline & Switzerland & Poultry, cattle, pig & $48,83,305,525,528,529,533,534,536,540$ & $\underline{260}$ \\
\hline & The Netherlands & Veal calves & $10,58,88,117,162,224,354,448,617,648,744,973$ & $\underline{21}$ \\
\hline & France & Dairy cattle & 23,58 & $\underline{13}$ \\
\hline & Germany & Dairy cattle & $10,117,540,1431,5447$ & 14 \\
\hline & Germany & $\begin{array}{l}\text { Swine, cattle, } \\
\text { poultry, horse }\end{array}$ & $\begin{array}{l}10,23,83,100,131,167,362,453,648 \\
925,973,1684,2699\end{array}$ & $\underline{43}$ \\
\hline & Germany & Dog & $10,23,69,160,224$ & $\underline{28}$ \\
\hline & U.S. & Dog, cat & $\begin{array}{l}23,38,44,68,69,131,167,405,410,443 \\
648,1011,1088,5174,5206,5220\end{array}$ & $\underline{261}$ \\
\hline \multirow[t]{4}{*}{ bla $\mathrm{CTX}-\mathrm{M}-14$} & The Netherlands & Veal calves & $10,57,952$ & $\underline{21}$ \\
\hline & France & Dairy cattle & $10,23,45,58$ & $\underline{13}$ \\
\hline & China & Pig, poultry & 10, 155, 206, 224, 359, 405, 602, 648, 2929, 2930, 2962 & $\underline{262}$ \\
\hline & China & Dog & $10,38,104,131,167,405,648,146,3630$ & $\underline{97}$ \\
\hline \multirow[t]{12}{*}{ bla $\mathrm{CTX}-\mathrm{M}-15$} & UK & Poultry & 57,156 & $\underline{259}$ \\
\hline & UK & Dog & $131,410,1284,2348,4184$ & $\underline{99}$ \\
\hline & The Netherlands & Veal calves & $58,59,88,361,410,648$ & $\underline{21}$ \\
\hline & Germany & Livestock & $10,88,90,167,410,617,648$ & $\underline{263}$ \\
\hline & Germany & Dairy cattle & $10,361,1508$ & $\underline{14}$ \\
\hline & $\begin{array}{l}\text { Germany, Denmark, Spain, } \\
\text { France, the Netherlands }\end{array}$ & Dog, horse & 131 & $\underline{264}$ \\
\hline & Germany, Italy & Dog, cat, cattle, horse & 648 & $\underline{96}$ \\
\hline & Germany & Dog & 410,3018 & $\underline{28}$ \\
\hline & U.S. & Dog, cat & $\begin{array}{l}23,38,44,68,69,131,167,405,410,443,617,648 \\
1011,1088,5174,5206,5220\end{array}$ & $\underline{261}$ \\
\hline & Mexico & Dog & 410,617 & $\underline{138}$ \\
\hline & China & Dog & $10,38,44,69,73,75,131,302,405,648,1700,2375$ & $\underline{97}$ \\
\hline & Nigeria & Poultry & 10,405 & $\underline{221}$ \\
\hline \multirow[t]{2}{*}{ bla ${ }_{\mathrm{SHV}-12}$} & Spain, Germany & Wild bird, dog, poultry & 23, 57, 117, 155, 362, 371, 453, 616, 1564, 2001 & $\underline{39}$ \\
\hline & China & Dog & $10,75,131,167,405,648,2375,3058$ & $\underline{97}$ \\
\hline
\end{tabular}


food-producing animals in the GERM-Vet monitoring program from 2008 to 2014 (35). This study detected the gene $b l a_{\text {СTX-M-1 }}$ in $69.9 \%$ of the ESBL producers, followed by bla $a_{\text {CTX-M-15 }}$ in $13.6 \%$, bla $a_{\text {CTX-M-14 }}$ in $11.7 \%$, bla $a_{\mathrm{TEM}-52}$ in $1.9 \%$, and $b l a_{\mathrm{SHV}-12}$ in $1.4 \%$. The genes $b l a_{\text {CTX-M-3 }}$ and $b l a_{\text {CTX-M-2 }}$ were identified in $1.0 \%$ and $0.5 \%$, respectively. The distribution of ESBL genes varies with regard to the different animal hosts and the isolation sites; for example, ESBL-producing E. coli were isolated more frequently from cases of enteritis in calves than from cases of bovine mastitis (35). Moreover, the geographical location also plays a role. For instance, the study by Day and co-workers identified the gene bla $_{\mathrm{CTX}-\mathrm{M}-1}$ as the most common among bovine ESBLproducing E. coli from Germany, while the gene $b l a_{\text {CTX-M-15 }}$ was most frequent in E. coli isolates of bovine origin from the United Kingdom (36). In ESBLproducing E. coli isolates from European companion animals, the gene $b l a_{\text {CTX-M-1 }}$ was most common, but the gene bla $a_{\mathrm{CTX}-\mathrm{M}-15}$ was also frequently identified $(24,37)$. In the United States, the gene bla $a_{\mathrm{CTX}-\mathrm{M}-15}$ was predominant among ESBL-producing E. coli from urinary tract infections of companion animals (38). The gene bla $a_{\mathrm{CTX}-\mathrm{M}-14}$ was less frequent in Europe, but in Asia among the most common ESBL genes in poultry, companion animals, and humans (24). The ESBL gene $b l a_{\mathrm{SHV}-12}$ was not frequently reported but was identified in ESBL-producing E. coli from poultry, dogs, and wild birds in Spain and Germany (39).

Worldwide, the most common ESBL gene in E. coli isolates of human origin is $b l a_{\mathrm{CTX}-\mathrm{M}-15}$, which is mainly associated with the pandemic E. coli clone O25:H4ST131 (40). This clone has been rarely identified in animals and if so, mostly in companion animals (24, $\underline{25}, \underline{41}, \underline{42})$. The production of various ESBLs has been demonstrated in animal $E$. coli isolates of a wide variety of multilocus sequence types $(24, \underline{35}, \underline{36}, \underline{43})$ (Table 1). According to Ewers and colleagues, an exclusive linkage of a specific bla gene or a distinct host with a certain sequence type (ST) is not evident (24). Nevertheless, ESBL-producing E. coli belonging to certain STs have been more frequently detected among animals and humans than others, namely ST10, ST23, ST38, ST88, ST131, ST167, ST410, and ST648, which are supposed to facilitate the spread of ESBL genes $(\underline{25}, \underline{36}$, $\underline{43}, \underline{44})$.

The dissemination of ESBL genes among E. coli from animals is mainly driven by horizontal gene transfer. ESBL genes are associated with several insertion sequences (ISs), such as ISEcp1, ISCR1, IS26, and IS10, transposons such as Tn2, and integrons ( $\underline{43}, \underline{45}, \underline{46})$. The majority of ESBL genes are plasmid-located, whereas the integration of ESBL genes in the chromosomal DNA of $E$. coli of animal origin has been rarely described (4749). The most prevalent replicon types identified among ESBL-carrying plasmids from E. coli are IncF, IncI1, IncN, IncHI1, and IncHI2, but plasmids of other replicon types also play a role in the dissemination of ESBL genes (47). The study by Day and co-workers identified 16 ESBL genes on 341 transferable plasmids, belonging to 19 replicon types (36). Despite this complexity, some plasmids that carry ESBL genes seem to be more successful than others. Plasmids carrying bla $a_{\mathrm{CTX}-\mathrm{M}-15}$ and belonging to the IncF family had been detected in the pandemic E. coli clone O25:H4-ST131 (47). The ESBL gene $b l a_{\text {CTX-M-1 }}$ was frequently identified on plasmids belonging to the IncN or IncI1 families, while $b l a_{\mathrm{CTX}-\mathrm{M}-14}$ was detected on IncK plasmids, and bla $a_{\mathrm{CTX}-\mathrm{M}-3}$ on IncL/M plasmids (47). IncI1, IncK, and IncX plasmids carried the ESBL gene bla $a_{\mathrm{SHV}-12}$ (39). A plasmid multilocus sequence typing scheme assigns members of the most common plasmid families to pSTs to trace epidemic plasmids (47). Some plasmids harbor additional resistance genes besides the ESBL gene, which may facilitate the coselection and persistence of ESBL gene-carrying plasmids even without the selective pressure of $\beta$-lactams, when the respective antimicrobial agents are used $(\underline{14}, \underline{43})$.

Many studies have tried to figure out whether ESBLproducing E. coli identified in humans might originate from animal reservoirs. Most of those studies could not find an obvious link, and most often, it was clearly shown that there was no link at all, animals and humans representing reservoirs of different clonal lineages that possessed various ESBL determinants $(50,51)$. Nevertheless, a Dutch study showed that a significant number of either human- or poultry-associated ESBL-producing E. coli isolates harbored genetically indistinguishable ESBL-encoding plasmids, suggesting that plasmids might be common vehicles that are likely transmitted through the food chain (52). Indeed, numerous studies have pointed out that chickens may represent a significant reservoir of ESBLs, which has become a considerable concern worldwide, although broad-spectrum cephalosporins are not approved for use in the poultry sector. ESBL-producing E. coli has been reported as a cause of infections in broilers and laying hens but also as a colonizer of living chickens and a contaminant of chicken meat at retail in several European and non-European countries, including countries in which the use of antimicrobial agents has been reduced following national action plans in veterinary medicine (53). 


\section{Acquired AmpC Cephalosporinases}

Although class A ESBL enzymes are the most common sources of acquired resistance to broad-spectrum cephalosporins in E. coli, class C $\beta$-lactamases, also known as AmpC-type enzymes, confer high-level resistance to those antimicrobial agents (54). The main plasmid-encoded AmpC enzymes are CMY-, DHA-, and ACC-type $\beta$-lactamases, with a higher prevalence of CMY-type enzymes worldwide (55). In animals, the majority of identified AmpC enzymes have been of the CMY type (Table 2) $(25, \underline{56})$. A recent study performed in Denmark identified CMY-2-producing E. coli isolates from poultry meat, poultry, and dogs (57). The study showed that the dissemination of bla $a_{\mathrm{CMY}-2}$ was mainly due to the spread of IncI1- $\gamma$ and IncK plasmids. In Sweden, though there are, in general, low rates of resistance to broad-spectrum cephalosporins, the occurrence of CMY-2-producing E. coli was demonstrated when Swedish chicken meat, Swedish poultry, and imported chicken meat were examined (58). The occurrence of CMY-2-producing E. coli in the Swedish broiler sector has been attributed to importation of 1-day old chicks from the United Kingdom, where broad-spectrum cephalosporins had been administered prophylactically to the young birds before exportation (59). It has also been shown that migratory birds may be colonized with CMY-2-positive E. coli (60). In a study conducted in Florida, a series of clonally unrelated CMY-2-producing E. coli isolates were recovered from feces of seagulls (61). They belong mainly to phylogroup D, corresponding to human commensal isolates, but some STs had previously been identified from human bacteremia. The $b l a_{\mathrm{CMY}-2}$ gene was mainly found on IncI1 plasmids, as reported with human isolates. Therefore, there was a significant correlation between the genetic features of those isolates and those known for human isolates in the United States, showing that seagulls were likely colonized by human isolates. This is an example showing that migratory birds crossing long distances, such as along the eastern United States coastline, may be reservoirs and therefore sources of such multidrug-resistant isolates, as is also exemplified in South America and Europe $(\underline{62}, \underline{63})$.

\section{Acquired Carbapenemases}

Carbapenemases have been rarely identified in animal E. coli. This is likely the consequence of a very weak selective pressure (if any) by carbapenems, since those antimicrobial agents are not (or only in rare cases for individual non-food-producing animals) prescribed in veterinary medicine. Nevertheless, there has been some concern in recent years since carbapenemase-producing bacteria, including E. coli, have been isolated from animals worldwide (64-66).

The first carbapenemase determinant identified in an animal E. coli isolate was VIM-1, which was recovered from a pig in Germany (67) (Table 3). Since then, other VIM-1-producing E. coli isolates have been identified in different pig farms in the same country $(68,69)$. This carbapenemase has so far never been found elsewhere in animal isolates. Other identified carbapenemases in E. coli are NDM-1 and NDM-5. NDM-1 has been iden-

TABLE 2 Examples of acquired bla $\mathrm{CMY}_{-2}$ genes in E. coli of animal origin from Europe, the North and South America, Asia, and Africa

\begin{tabular}{|c|c|c|c|}
\hline Geographical origin & Source & Sequence type(s) & Reference \\
\hline Germany & Pig & 625 & $\underline{265}$ \\
\hline Spain & $\begin{array}{l}\text { Wild bird } \\
\text { (yellow-legged gull) }\end{array}$ & 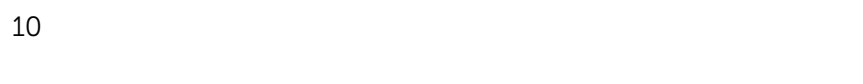 & $\underline{266}$ \\
\hline $\begin{array}{l}\text { Denmark, Germany, } \\
\text { France }\end{array}$ & $\begin{array}{l}\text { Poultry and poultry } \\
\text { meat, dog }\end{array}$ & $\begin{array}{l}10,23,38,48,68,69,88,93,115,117,131,206,212,219,297,350 \\
361,372,405,410,428,448,457,546,616,746,754,919,963 \\
1196,1056,1303,1518,1585,1594,1640,1775,2040,2144 \\
2168,2196,2558,3272,3574,4048,4124,4125,4240,4243\end{array}$ & $\underline{57}$ \\
\hline Portugal & Poultry & $57,117,429,2451$ & $\underline{267}$ \\
\hline Switzerland & Poultry meat & 38,1564 & $\underline{268}$ \\
\hline Switzerland & Poultry & $3,9,61,527,530,535,539$ & \\
\hline Austria & Wild bird (rook) & 224 & $\underline{60}$ \\
\hline U.S. & Poultry meat & 131 & $\underline{269}$ \\
\hline Brazil & Poultry & $453,457,1706$ & $\underline{270}$ \\
\hline China & Pig, poultry & $\begin{array}{l}10,48,69,101,155,156,354,359,362,457,648,1114,1431 \\
2294,2690,3014,3244,3245,3269,3376,3402,3403,3404\end{array}$ & $\underline{271}$ \\
\hline Japan & Cattle & 1284,2438 & $\underline{272}$ \\
\hline Japan & Dog & $10,354,493,648,3557$ & $\underline{273}$ \\
\hline Tunisia & Poultry & $117,155,2197$ & $\underline{274}$ \\
\hline
\end{tabular}


TABLE 3 Examples of acquired carbapenemase genes in E. coli of animal origin from Europe, North and South America, Africa, Australia, and Asia

\begin{tabular}{|c|c|c|c|c|}
\hline $\begin{array}{l}\text { Carbapenemase } \\
\text { gene }\end{array}$ & Geographical origin & Source & Sequence types & Reference \\
\hline$b a_{\mathrm{NDM}-1}$ & China, U.S. & Dog, cat, pig & $167,1695,1585,1721,359$ & $\underline{70}, \underline{275}, \underline{276}$ \\
\hline bla $a_{N D M-5}$ & China, Algeria, India & Dog, pig, cow, duck & $\begin{array}{c}48,54,90,156,165,167,410,648,1114,1178 \\
1234,1437,2439,3331,4429,4463,4656\end{array}$ & $\underline{74}, \underline{75}, \underline{277}-\underline{279}$ \\
\hline blaviM-1 & Germany & Seafood, pig & 10,88 & $\underline{67}, \underline{68}, \underline{280}, \underline{281}$ \\
\hline bla $a_{\text {MP }-4}$ & Australia & Silver gull & $\begin{array}{c}48,58,167,189,216,224,345,354,541,542,744, \\
746,1114,1139,1178,1421,2178,4657,4658,\end{array}$ & $\underline{76}$ \\
\hline bla OXA-48 & $\begin{array}{l}\text { Germany, U.S., France, } \\
\text { Lebanon, Algeria }\end{array}$ & Dog, cat, chicken & $38,372,648,1196,1431$ & $\underline{77}-\underline{79}, \underline{261}$ \\
\hline bla OXA-181 & Italy & Pig & 359,641 & $\underline{80}$ \\
\hline bla $a_{\mathrm{KPC}-2}$ & Brazil & Dog & 648 & $\underline{287}$ \\
\hline
\end{tabular}

tified in the United States and in China, in isolates recovered from dogs, cats, and pigs $(70,71)$. NDM-5 has been detected in China, India, and Algeria, from cattle, poultry, dogs, cats, and fish (2-75). The gene encoding IMP-4 has been identified in E. coli isolates recovered from silver gulls in Australia (76). Interestingly, the OXA-48 carbapenemase, which is the most prevalent carbapenemase in human enterobacterial isolates in Europe, has been found in E. coli isolates recovered from dogs, cats, and chickens in Germany, France, Lebanon, Algeria, and the United States (37, 77-79). Finally, the OXA-181 enzyme, which is a variant of OXA-48 increasingly reported in humans, has recently been identified in animals as well, being found in clonally unrelated E. coli isolates recovered from pigs in Italy (0). Even though the class A $\beta$-lactamase KPC is one of the most commonly identified carbapenemases in human isolates in some parts of the world, including in North America, China, and some European countries (Italy, Greece, Poland), it has not yet been identified in animal $E$. coli isolates so far $(\underline{81}, \underline{82})$, except for a single bla $a_{\mathrm{KPC}-2}$-carrying isolate from a dog in Brazil that suffered from a urinary tract infection (287).

Overall, and notably, the different carbapenemase genes that have been identified among animals in different countries reflect the types of carbapenemases known to be the most prevalent in human isolates in those countries. Considering that carbapenems are not used in veterinary medicine, it remains to be determined which antimicrobial selective pressure is responsible for the selection of such carbapenemase producers in animals. Penicillins, however, are excellent substrates for any kind of $\beta$-lactamases, including carbapenemases, and therefore their use might correspond to a selective pressure anyhow. In addition, it remains to be evaluated whether animals may act as potential sources of transmission of those resistance traits toward humans or if, conversely, this epidemiology just reflects the consequence of a higher prevalence in humans that may eventually target animals through an environmental dissemination. Since the occurrence of carbapenemaseproducing Enterobacteriaceae in animals is marginal, it therefore does not correspond to a significant threat to human medicine (65).

\section{RESISTANCE TO QUINOLONES AND FLUOROQUINOLONES}

Quinolones and fluoroquinolones are important antimicrobial agents for treating various types of infections in both humans and animals. They are known to be bactericidal against virtually all bacteria. Resistance to these antimicrobial agents is usually due to mutations in the drug targets, namely, the genes for DNA gyrase and topoisomerase IV, but other mechanisms such as reduced permeability of the outer membrane, protection of the target structures, or upregulated efflux pumps may also play a role ( $\underline{83})$.

\section{Resistance to (Fluoro)Quinolones by Chromosomal Target Site Mutations}

The primary target of (fluoro)quinolones in E. coli is the gyrase, which consists of two GyrA subunits and two GyrB subunits. Topoisomerase IV constitutes a secondary target in Gram-negative bacteria. This enzyme consists of two ParC and two ParE subunits. Most mutations were found within the quinolone resistancedetermining region, which is between Ala67 and Gln107 in GyrA, and most frequently mutations occur at codons 83 and $87(83)$. Single mutations in the gene gyrA may confer resistance to quinolones, but for resistance to fluoroquinolones, further mutations within $g y r A$ and/or $\operatorname{par} C$ are needed. Most parC mutations occur at codons 80 and 84 (83). In clinical E. coli isolates from com- 
panion animals, different combinations of mutations were detected at codons 83 and 87 in gyrA and at codons 80 and 84 in $\operatorname{parC}(\underline{84}, \underline{85})$. Mutations within gyrA and parC were also described in E. coli isolates originating from diseased food-producing animals $(\underline{86}, \underline{87})$.

\section{Resistance to (Fluoro)Quinolones by Plasmid-Borne Resistance Mechanisms}

Since the identification of the first plasmid-mediated quinolone resistance (PMQR) determinant, qnrA1, in 1997, there is serious concern about the global dissemination of PMQR genes $(\underline{88}, \underline{89})$. Several plasmidencoded resistance mechanisms have been identified, including (i) Qnr-like proteins (QnrA, QnrB, QnrC, QnrD, and QnrS) which protect DNA from quinolone binding, (ii) the $\mathrm{AAC}\left(6^{\prime}\right)$-Ib-cr acetyltransferase that modifies certain fluoroquinolones such as ciprofloxacin and enrofloxacin, and (iii) active efflux pumps (QepA and OqxAB). Overall, these resistance determinants do not confer a high level of resistance to quinolones (or fluoroquinolones), but rather, confer reduced susceptibility to those antimicrobial agents. However, they might contribute to the selection of isolates exhibiting higher levels of resistance through additional chromosomally encoded mechanisms (89).

PMQRs have been identified widely among human isolates but also among animal isolates. Especially in China, numerous studies have shown high prevalences of Qnr, AAC(6')-Ib-cr, and QepA determinants among food-producing animals (86, 90), and some studies highlighted an increased prevalence through the years (91). A Europe-wide retrospective study identified the genes qnrS1 and qnrB19 in E. coli isolates from foodproducing animals, namely, poultry, cattle, and pigs (92). PMQRs were detected not only in food-producing animals, but also in companion animals. In E. coli isolates from diseased companion animals, the genes $q n r S 1$, qnrB1, qnrB4, and qnrB10 were identified (84). The gene $q n r B 19$ was described in equine E. coli isolates $(93,94)$. The replicon types often associated with plasmids that carried the PMQR genes qnrS1 and qnrB19 are IncN and IncX but also include several others (47, 94, 95).

In E. coli belonging to several STs of companion animal origin, the gene $a a c\left(6^{\prime}\right) I b-c r$ was identified (96-99). This gene was located on plasmids of the IncF family, and a $b l a_{\mathrm{CTX}-\mathrm{M}}$ ESBL gene, usually $b l a_{\mathrm{CTX}-\mathrm{M}-15}$, was often colocated $(96,98)$. Furthermore, $a a c\left(6^{\prime}\right) I b-c r$ was described in E. coli isolates from the feces of French cattle, where it was also colocated with bla $a_{\text {CTX-M-15 }}$ on plasmids belonging to the IncF family (100). The gene $q e p A$ was identified in E. coli of companion animal origin belonging to different STs (97). Plasmids of the IncF family harbored qepA in $E$. coli from food-producing and companion animals (101). The PMQR gene oq $x A B$ was identified in unrelated E. coli isolates from foodproducing animals and located on different plasmids belonging to the IncF and IncHI2 families (102). The case of OqxAB is peculiar since this resistance determinant confers reduced susceptibility not only to quinolones (such as flumequine), but also to other drugs such as trimethoprim and chloramphenicol that are also used in veterinary medicine. Therefore, this resistance determinant encompasses different families of antimicrobial agents to which resistance (or reduced susceptibility) can be coselected (103).

\section{RESISTANCE TO AMINOGLYCOSIDES}

Aminoglycosides are drugs of natural origins whose producers can be found in the genus Streptomyces (104, 105) and Micromonospora, and they are often used in combination with another antimicrobial (mostly a $\beta$-lactam) to exploit their rapid bactericidal action for treating complicated infections such as sepsis, pneumonia, meningitis, and urinary tract/abdominal infections, both in humans and animals, including food-producing animals and companion animals (106). The most frequently used molecules in veterinary medicine are neomycin and derivatives of streptomycin. Gentamicin, kanamycin, and paromomycin are used as well. Amikacin is reserved for the treatment of infections in pets and horses (106).

Aminoglycosides affect a broad spectrum of pathogens among Gram-negative and -positive bacterial species, interfering with translation (107). Two major issues could limit the therapeutic power of these important molecules: the first is linked to their toxicity. Nevertheless, this issue is managed by opportune therapeutic regimens based on recent advances in the understanding of aminoglycoside pharmacodynamics (108). The second issue is the emergence of bacterial resistance linked to the usage of aminoglycosides, which has disseminated globally. The following subsections provide an overview of mechanisms of resistance toward aminoglycosides and their epidemiology in E. coli of animal origin.

\section{Resistance to Aminoglycosides by Target Modifications}

Resistance to aminoglycosides can develop by target mutations involving the 16S RNA and/or the S5 and 
S12 ribosomal proteins $(107,109,110)$. However, this strategy is successful in conferring high-level resistance only in bacterial species with a limited number of copies of 16S RNA encoding operons. E. coli harbors seven copies of such operons, making the establishment of aminoglycoside resistance by point mutations rather improbable.

Modification of the target site of aminoglycosides can be achieved also by methylation of residues G1405 and A1408 of site A of the 16S RNA, resulting in highlevel resistance to amikacin, tobramycin, gentamicin, and netilmicin (109). The 16S RNA methylases, including ArmA, RmtA/B/C/D/E/F/G/H, and NmpA, originated from natural aminoglycoside producers as self-defense against antimicrobial production (104). The first detection of ArmA dates back to 2003, when Galimand and colleagues reported the enzyme in a Klebsiella pneumoniae isolate from a human and the respective gene on a conjugative plasmid (111). Since then, the $\operatorname{arm} A$ gene has been reported in several enterobacteria, Acinetobacter baumannii, and Pseudomonas aeruginosa isolates (112-116). The dissemination of the armA gene is favored by its location on the composite transposon Tn1548, which also carries genes coding for sulfonamide resistance, which in turn is located on self-transmissible plasmids belonging to several incompatibility groups (117). Emergence of ArmA in E. coli from animals was reported in 2005 in Spain in one pig (118), whereas the first report of E. coli producing RmtB was in 2007 in China by Chen and co-workers who reported a prevalence of $32 \%(n=49 / 152)$ among healthy pigs in farms (119). In an investigation conducted in China in 2008, Du et al. reported the presence of ArmA and RmtB in E. coli from diseased poultry, with an occurrence of $10 \%$ $(n=12 / 120)(120)$. Later, Liu et al. reported the presence of E. coli ArmA and RmtB producers among various food-producing animals in 2009 to 2010, with an occurrence of $1.27 \%$ and $11.5 \%$ for ArmA and RmtB, respectively ( $n=2$ and 18/157) (121). RmtB was found in E. coli isolates associated with bovine mastitis in China in 2013 to 2014, with an occurrence of 5.3\% $(n=13 / 245)$ (122). Yang and colleagues reported the presence of $E$. coli producing $\mathrm{RmtD}$ in diseased chickens in 2012 to 2014 in China. The enzyme co-occurred with RmtB with a prevalence of $8.3 \%(n=3 / 36)$. In the same study, other methylases were found, namely, RmtB together with ArmA in $8.3 \%$ of isolates $(n=3 / 36)$, RmtB alone in $72.2 \%$ of isolates $(n=26 / 36)$, and ArmA in $11.1 \%$ of isolates $(n=4 / 36)(123)$.

More recently, a scattered porcine E. coli isolate harboring the armA gene was detected in Italy. The isolate was multidrug-resistant, notably harboring the $b l a_{\mathrm{CMY}-2}, b l a_{\mathrm{OXA}-181}$, and $m c r-1$ genes (0). Recently, two E. coli isolates producing RmtB were reported from diseased bovines in France. The gene colocalized on an IncF33:A1:B1 plasmid with $b a_{\text {CTX-M-55 }}$ and in one isolate also with the fos $A 3$ gene (124). The RmtD variant has been found less frequently. Other than the report from Yang et al. (123), another recent report has been published from Brazil, on one E. coli isolate from a diseased horse producing $\mathrm{RmtD}$ and harboring the $b{ } a_{\mathrm{CTX}}$ $\mathrm{M}-15$ and $a a c\left(6^{\prime}\right)-\mathrm{Ib}$-cr genes (125). The RmtE methylase was reported for the first time from commensal E. coli isolates from healthy calves in the United States (126). Later, two E. coli isolates were identified as RmtE producers in diseased food-producing animals in China, from 2002 to 2012 (127). Reports on RmtA are also quite infrequent, with a recent one from Zou et al., who found a frequency of $10 \%$ of $r m t A$ gene occurrence among $89 \mathrm{E}$. coli isolates from giant pandas in China (128). To the best of our knowledge, RmtF/G/H enzymes have not yet emerged in E. coli, and NmpA has never been reported from animals. Overall, it can be stated that methylases have not widely disseminated since their discovery, probably for reasons related to fitness $(129,130)$. An exception is in China, where probably the antimicrobial usage, not only relative to aminoglycosides, may play a role in the emergence and dissemination of these enzymes. On the contrary, aminoglycoside-modifying enzymes have disseminated globally, and an overview of those most frequently encountered in animals is provided in the next subsection.

\section{Resistance to Aminoglycosides by Enzymatic Inactivation}

The inactivation of aminoglycosides is conducted by enzymes which modify the molecules so that they become unable to reach or bind to the target site. Currently, three types of aminoglycoside-modifying enzymes are known, and according to the modifying group that is linked to the aminoglycosides, they are classified as acetyltransferases, nucleotidyltransferases, and phosphotransferases.

The aminoglycoside acetyltransferases catalyze the addition of an acetyl group $\left(\mathrm{CH}_{3} \mathrm{CO}\right)$ to an amine group $\left(-\mathrm{NH}_{2}\right)$ at positions $1,2,3$, or 6 of the aminoglycoside structure, which determines the subgroup of the enzyme (131). For each enzyme, several variants have been reported, and they are usually defined by a roman number. $\mathrm{AAC}(3)-\mathrm{II} / \mathrm{IV}$ and AAC(6)-Ib are the most frequently encountered acetyltransferases among E. coli of human and animal origins. They have been globally reported from several hosts $(\underline{128}, \underline{132-140})$. 
Among aminoglycosides, the nucleotidyltransferases ANT ( $\left.2^{\prime \prime}\right)$ and ANT( $\left.3^{\prime \prime}\right)$ are most commonly found in Gram-negative bacteria. ANT(2") and ANT( $\left.3^{\prime \prime}\right)$ are encoded by the genes aadB and aadA, respectively (131), which are both frequently located on gene cassettes in class 1 integrons. These genes have also spread globally, and they have been found in E. coli from animals including pets, wild animals, and food-producing animals $(134,141-148)$.

Among the aminoglycoside phosphotransferases, APH(6)-Ia and APH(6)-Id encoded by the strA and strB genes, respectively, are most commonly encountered in E. coli worldwide. They mediate resistance to streptomycin and are frequently associated with a unique mobile element, sometimes together with the aph(3")-I/II genes mediating kanamycin resistance. These resistance mechanisms have been found in several hosts including wild rabbits (145), cattle (149-152), poultry $(\underline{153}, \underline{154})$, and swine (155-157).

\section{RESISTANCE TO FOSFOMYCIN}

Fosfomycin inhibits the MurA enzyme, which is involved in peptidoglycan synthesis. The use of fosfomycin in veterinary medicine is limited to the treatment of infections caused by a number of Gram-positive and Gram-negative pathogens, including E. coli, mainly in piglets and broiler chickens $(\underline{158}, \underline{159})$. Two major fosfomycin resistance mechanisms have been described: (i) mutations in the $g l p T$ and $u h p A / T$ genes encoding proteins involved in the fosfomycin uptake system and (ii) the acquisition of fosfomycin-modifying enzymes such as the metalloenzymes FosA, FosB, and FosX or the kinases FomA and FomB (160). Most of the fos-like genes are plasmid-borne, and plasmids carrying the fos genes commonly carry additional resistance genes (124, $161,162)$ that increase the risk of coselection of fosfomycin resistance under the selective pressure by other antimicrobial agents.

A considerable number of studies report acquired fosfomycin resistance among E. coli of animal origin. Isolates carrying the plasmid-mediated fos $A$ gene have been reported from companion animals. The first cases were reported in China in 2012 and 2013 from dogs and cats $(163)$. Another study described a high prevalence of FosA3-producing E. coli in pets and their owners, highlighting the transmission of fosfomycin-resistant E. coli isolates between humans and animals (164). Another Chinese study described the fosA3 gene in E. coli from fresh pork and chicken meat (165). In that study, the fos $A 3$ gene was often found together with
ESBL genes $\left(b l a_{\mathrm{CTX}-\mathrm{M}-55}, b l a_{\mathrm{CTX}-\mathrm{M}-15}\right.$, or $\left.b l a_{\mathrm{CTX}-\mathrm{M}-123}\right)$ on plasmids of 78 to $138 \mathrm{~kb}$ in size. In a recent French study, the emergence of plasmids carrying multiple resistance determinants including fos $A 3$, bla $a_{\text {CTX-M-55 }}$, $r m t B$, and $m c r-1$ was reported in various animal species (124). In that study, it was speculated that this plasmid could have an Asian origin since bla $a_{\text {CTX-M-55 }}$ is the second most prevalent ESBL gene in that part of the world. In 2013, the complete sequence of the 76,878 -bp plasmid $\mathrm{pHN7A} 8$ from a dog in China was determined. This plasmid represents a $\mathrm{F} 33: \mathrm{A}^{-}: \mathrm{B}^{-}$-type epidemic plasmid that carried the resistance genes $b l_{\mathrm{CTX}-\mathrm{M}-65}$, fos $A 3$, and $r m t B$ (166). Plasmids with similar fosA3 regions were reported from E. coli isolates of pig (167), duck (168), and chicken origin (169). The widespread occurrence of the fos $A 3$ gene in China was demonstrated in a study that identified 12/892 E. coli isolates as fosA3-positive. These isolates originated from pigs, chickens, ducks, a goose, and a pigeon (170). Furthermore, the analysis of 1,693 E. coli isolates from various animal species identified 97 fosA3-positive isolates from beef cattle, pigs, broiler chickens, stray cats, stray dogs, and wild rodents in China (171). Recently, several epidemic fosA3carrying multiresistance plasmids of diverse incompatibility groups have been identified to be disseminated among E. coli from pigs, dairy cattle, and chickens in northeast China (162). Some of these plasmids have been sequenced completely, including the plasmids pECM13 from cattle $\left(113,006 \mathrm{bp}\right.$, IncI1, and coharboring bla ${ }_{\text {CTX- }}$ $\mathrm{M}-14, r m t B$, aadA2, and $\left.b l a_{\mathrm{TEM}-1}\right), \mathrm{pECB} 11$ from chicken [92,545 bp, F33: $\mathrm{A}^{-}: \mathrm{B}^{-}$, and coharboring bla CTX-M-55, floR, cfr, bla $a_{\mathrm{TEM}-1}$, tet (A), strA, and strB], and pECF12 from chicken $\left[77,822 \mathrm{bp}, \mathrm{F} 33: \mathrm{A}^{-}: \mathrm{B}^{-}\right.$, and coharboring $b_{\text {bTX-M-3 }}, r m t B$, tet $(\mathrm{A}), \operatorname{str} A$, and $\left.\operatorname{str} B\right]$. E. coli isolates from pigs harboring the fos $A 3$ gene were also detected in Taiwan (172).

\section{RESISTANCE TO TETRACYCLINES}

Tetracyclines are widely used in veterinary medicine. A summary of sales data in the 25 European Union and European Economic Area countries revealed that tetracyclines accounted for $37 \%$ of the total sales of veterinary antimicrobial agents, followed by penicillins $(23 \%)(173)$. As a consequence of the selective pressure imposed by the widespread use of tetracyclines, many bacteria-including E. coli-have developed tetracycline resistance. According to the tetracycline resistance gene nomenclature center (https://faculty.washington .edu/marilynr/), nine tetracycline efflux genes [tet (A), tet $(\mathrm{B}), \operatorname{tet}(\mathrm{C}), \operatorname{tet}(\mathrm{D}), \operatorname{tet}(\mathrm{E}), \operatorname{tet}(\mathrm{G}), \operatorname{tet}(\mathrm{J}), \operatorname{tet}(\mathrm{L})$, and 
tet $(\mathrm{Y})$ ], two tetracycline resistance genes encoding ribosome protective proteins $[\operatorname{tet}(\mathrm{M})$ and $t e t(\mathrm{~W})]$, and one gene coding for an oxidoreductase that inactivates tetracyclines $[t e t(\mathrm{X})]$ have been identified in E. coli. The major mechanisms of tetracycline resistance encountered in E. coli of animal origin include (i) the active efflux by proteins of the major facilitator superfamily and (ii) ribosome protection. A PubMed search for tetracycline resistance genes in E. coli of animal origin revealed that not all of these 12 tet genes occur in E. coli from animal sources. The following examples provide an overview of the distribution of tet genes among E. coli from various animal sources.

Among $155 \mathrm{E}$. coli isolates from fecal samples of cattle in Korea, the genes tet $(\mathrm{A})$, tet $(\mathrm{B})$, and tet $(\mathrm{C})$ were detected in 72,70 , and nine isolates, respectively. Two isolates each carried $\operatorname{tet}(\mathrm{A})+\operatorname{tet}(\mathrm{B}) \operatorname{or} \operatorname{tet}(\mathrm{B})+\operatorname{tet}(\mathrm{C})$ (174). In $99 \mathrm{E}$. coli isolates from bovine mastitis in the United States collected from 1985 to 1987 and in 2009, the genes $\operatorname{tet}(\mathrm{A}), \operatorname{tet}(\mathrm{B})$, and $\operatorname{tet}(\mathrm{C})$ were detected, with tet $(\mathrm{C})$ being present in more than half of the investigated isolates in each of the two time periods (175). Of 129 E. coli isolates from cases of bovine mastitis in the United States, 68 carried the gene tet $(\mathrm{C})$, while another 14 isolates harbored $\operatorname{tet}(\mathrm{C})+\operatorname{tet}(\mathrm{A})(\underline{176})$. A study in Switzerland identified the genes tet $(\mathrm{A})$, tet $(\mathrm{B})$, and tet $(\mathrm{A})$ $+\operatorname{tet}(\mathrm{B})$ in 24,16 , and two E. coli isolates from bovine mastitis (177). In the same study, the genes tet $(\mathrm{A})$, tet $(\mathrm{B})$, tet $(\mathrm{C})$, and tet $(\mathrm{A})+\operatorname{tet}(\mathrm{B})$ were detected in 60 , five, one, and two E. coli isolates, respectively, from diarrhea and enterotoxemia in pigs (177). In 99 tetracycline-resistant E. coli isolates from pigs in Spain, the genes tet $(\mathrm{A})(n=$ $46), \operatorname{tet}(\mathrm{B})(n=12)$, and tet $(\mathrm{A})+\operatorname{tet}(\mathrm{B})(n=28)$ but also $\operatorname{tet}(\mathrm{A})+\operatorname{tet}(\mathrm{M})(n=11)$ and $\operatorname{tet}(\mathrm{A})+\operatorname{tet}(\mathrm{B})+\operatorname{tet}(\mathrm{M})(n=$ 2 ) were detected (178). The tet $(\mathrm{M})$ gene was shown by Southern blot hybridization to be located on plasmids. In a study in Germany, either the genes tet(A) $(n=71)$, tet $(\mathrm{B})(n=46)$, and $\operatorname{tet}(\mathrm{C})(n=3)$ alone or the combinations of the genes tet $(\mathrm{A})+\operatorname{tet}(\mathrm{B})(n=2), \operatorname{tet}(\mathrm{A})+$ $\operatorname{tet}(\mathrm{C})(n=2), \operatorname{tet}(\mathrm{A})+\operatorname{tet}(\mathrm{D})(n=3), \operatorname{tet}(\mathrm{A})+\operatorname{tet}(\mathrm{M})(n=$ $1), \operatorname{tet}(\mathrm{B})+\operatorname{tet}(\mathrm{M})(n=2), \operatorname{tet}(\mathrm{B})+\operatorname{tet}(\mathrm{C})(n=2)$, and tet $(\mathrm{B})+\operatorname{tet}(\mathrm{D})+\operatorname{tet}(\mathrm{M})(n=1)$ were detected in E. coli from pigs (179). Among 283 tetracycline-resistant extra-intestinal pathogenic E. coli isolates from pigs in China, the genes tet $(\mathrm{A})(n=68), \operatorname{tet}(\mathrm{B})(n=141), \operatorname{tet}(\mathrm{C})(n=3)$, tet $(\mathrm{D})(n=1)$, and tet $(\mathrm{G})(n=108)$ were identified (156). A wide variety of tet genes was also seen among 73 tetracycline-resistant E. coli isolates from broilers in Iran, including the gene tet $(\mathrm{E})$ alone $(n=1)$ or in the combinations tet $(\mathrm{E})+\operatorname{tet}(\mathrm{C})(n=4), \operatorname{tet}(\mathrm{E})+\operatorname{tet}(\mathrm{D})+$ tet (M) $(n=2), \operatorname{tet}(\mathrm{E})+\operatorname{tet}(\mathrm{D})+\operatorname{tet}(\mathrm{A})+\operatorname{tet}(\mathrm{G})(n=3)$, and $t e t(\mathrm{E})+\operatorname{tet}(\mathrm{M})+\operatorname{tet}(\mathrm{A})+\operatorname{tet}(\mathrm{B})+\operatorname{tet}(\mathrm{C})(n=1)(180) \cdot . \mathrm{In}$ 33 E. coli isolates from cases of septicemia among laying hens in Switzerland, the genes $\operatorname{tet}(\mathrm{A})$ and $\operatorname{tet}(\mathrm{B})$ were found in 21 and 10 isolates, respectively, while two isolates carried neither tet $(\mathrm{A}), \operatorname{tet}(\mathrm{B})$, nor $\operatorname{tet}(\mathrm{C})(\underline{177})$. In the same study, the genes $\operatorname{tet}(\mathrm{A})$ and $\operatorname{tet}(\mathrm{B})$ were detected in eight and nine E. coli isolates from urinary tract infections in dogs and cats, respectively. The same two tet genes were also found in E. coli isolates from healthy dogs and cats in Spain (181). A large-scale study of tet genes in 325 nonclinical $E$. coli isolates from various animal sources in the United States identified the gene tet (B) in isolates from a goose, a duck, and a deer; the genes tet $(\mathrm{A})$ and $t e t(\mathrm{~B})$ in isolates from turkeys, cats, goats, and cows; tet $(\mathrm{A})$, tet $(\mathrm{B})$, and $\operatorname{tet}(\mathrm{C})$ in isolates from dogs, sheep, and horses; and tet $(\mathrm{A}), \operatorname{tet}(\mathrm{B}), \operatorname{tet}(\mathrm{C})$, and tet $(\mathrm{M})$ in isolates from pigs and chickens (182). However, in that study neither tet $(\mathrm{E})$ nor tet $(\mathrm{G})$, tet $(\mathrm{L})$, or tet $(\mathrm{X})$ were detected in the $325 \mathrm{E}$. coli isolates. Among 58 tetracycline-resistant $E$. coli isolates from giant pandas, the genes tet $(\mathrm{A})$, tet $(\mathrm{E})$, and/or tet $(\mathrm{C})$ were detected in 33, 24, and four isolates, respectively (128).

These examples show that different tet genes-alone or in combination with others-occur at different frequencies in E. coli isolates from different animal sources and/or geographic regions. In general, the genes tet $(\mathrm{A})$ and tet $(\mathrm{B})$ were the most prevalent tetracycline resistance genes in E. coli of animal origin. Both of these genes are part of small nonconjugative transposons, Tn1721 [tet $(\mathrm{A})](\underline{183})$ and $\operatorname{Tn} 10[\operatorname{tet}(\mathrm{B})](184)$, which are often integrated into conjugative and nonconjugative plasmids. Several of the aforementioned examples revealed the presence of more than a single tet gene in the same isolate. This might be explained by the observation that several tet genes are frequently found on plasmids or other mobile genetic elements which may have been acquired by the respective $E$. coli isolates at different times and under different conditions. When other resistance genes are colocated with a tet gene on the same plasmid, such a plasmid can be acquired under the selective pressure imposed by the use of antimicrobial agents other than tetracyclines. Multidrug resistance plasmids that also carry tet genes have been detected in E. coli from bovine mastitis in Germany. Here, the gene tet(A) was located on IncHI2/IncP plasmids of ca. $225 \mathrm{~kb}$, which also harbored the resistance genes $b l a_{\mathrm{CTX}-\mathrm{M}-2}$, bla $a_{\text {TEM-1 }}$, sul1, sul2, $d f r A 1$, and aadA1 (14). IncI1 plasmids that range in size from 90 to $120 \mathrm{~kb}$ and carry the resistance gene tet $(\mathrm{A})$ along with the genes $b l a_{\mathrm{SHV}-12}$, addA1, cmlA1, and aadA2 or the genes bla $a_{\mathrm{SHV}-12}, q a c G$, and aadA6 were identified in E. coli isolates from wild 
birds, dogs, and poultry in Spain or Germany (39). In canine E. coli isolates from Brazil, several multiresistance plasmids were identified. These included (i) a ca. $250-\mathrm{kb}$ IncFIB/IncHI2 plasmid that carried the gene tet $(\mathrm{B})$ together with the resistance genes $b l a_{\text {CTX-M-2, }}$, sul1, aadA29, strA, and $\operatorname{str} B$; (ii) a ca. 240-kb IncFIC plasmid that harbored the $\operatorname{tet}(\mathrm{A})$ gene together with the resistance genes $b l a_{\mathrm{CMY}-2}, c m l A$, floR, $\operatorname{str} A, \operatorname{str} B, \operatorname{sul} 1$, sul3, and adA7; (iii) a 240-kb IncHI2 plasmid with the resistance genes $b l a_{\mathrm{CTX}-\mathrm{M}-2}, \operatorname{sul} 1$, aadA29, $\operatorname{str} A$, and $\operatorname{str} B$; and (iv) a $40-\mathrm{kb}$ IncFIB/IncN plasmid with the resistance genes tet(A), sul1, $d f_{r A 16}$, and $d f_{r} A 29$ (185). Lastly, an $81-\mathrm{kb}$ plasmid that carried the resistance genes qnrS1, bla CTX-M-14, $_{\text {bla }}$ TEM-1 $_{\text {, floR, }}$ and tet (A) was found in an E. coli isolate from a pig in China (186). These few examples illustrate that tet gene-carrying multiresistance plasmids occur in E. coli of different animal species in different parts of the world. Given the widespread use of tetracyclines in veterinary medicine, such plasmids not only facilitate the dissemination of certain tet genes, but also support the coselection and persistence of other resistance genes.

\section{RESISTANCE TO PHENICOLS}

Phenicols are broad-spectrum antimicrobial agents of which nonfluorinated (e.g., chloramphenicol) and fluorinated (e.g., florfenicol) derivatives are used in veterinary medicine. Due to its toxicity and important adverse effects in humans, such as dose-unrelated irreversible aplastic anemia, dose-related reversible bone marrow suppression, and Gray syndrome in neonates, chloramphenicol and its derivatives thiamphenicol and azidamfenicol were banned in 1994 in the European Union from use in food-producing animals (187). Currently, the use of nonfluorinated phenicols in animals is limited to the treatment of companion animals and pets. However, the fluorinated derivative florfenicol is licensed for the treatment of bacterial infections in food-producing animals (187).

Phenicol resistance in E. coli of animal origin is mediated by three major mechanisms: (i) enzymatic inactivation of nonfluorinated phenicols by chloramphenicol acetyltransferases encoded by cat genes, (ii) active efflux of nonfluorinated phenicols ( $\mathrm{cmlA}$ genes) or fluorinated and nonfluorinated phenicols (floR genes) by major facilitator superfamily proteins, and (iii) target site methylation by an rRNA methylase encoded by the multiresistance gene $c f r$, which confers resistance to five classes of antimicrobial agents, including fluorinated and nonfluorinated phenicols (187).
Among 102 E. coli isolates from pigs in China, 91 $(89 \%)$ were resistant to chloramphenicol. The genes cat $A 1$ and catA 2 but also the cassette-borne gene $\mathrm{cmlA}$ were detected in $58 \%, 49 \%$, and $65 \%$, respectively, of the chloramphenicol-resistant isolates. In addition, the gene $f l o R$ was detected in $57 \%$ of the florfenicol-resistant isolates and in $52 \%$ of chloramphenicol-resistant isolates (188). In a study of 318 ETEC, non-ETEC from cases of diarrhea, and commensal E. coli isolates from healthy pigs in Canada, the genes catA1, $c m l A$, and floR were detected among the chloramphenicol-resistant isolates. The gene catA1 was significantly more frequent in ETEC than in non-ETEC and commensal E. coli (189). The genes floR and $c m l A$ were detected among 48 E. coli isolates from calves with diarrhea. Of the 44 isolates for which florfenicol MICs were $\geq 16 \mathrm{mg} /$ liter, 42 carried the floR gene. Twelve E. coli isolates were positive for $\mathrm{cmlA}$, and their corresponding chloramphenicol MICs were $\geq 32 \mathrm{mg} /$ liter. In addition, eight isolates were positive for floR and $c m l A$, and their florfenicol and chloramphenicol MICs were $\geq 64 \mathrm{mg} /$ liter (190). In a study of antimicrobial resistance in German E. coli isolates from cattle, pigs, and poultry, not further specified cat $A$ genes were found in seven isolates from cattle and six isolates each from pigs and poultry. Moreover, $\mathrm{cmlA1} 1$-like genes were detected in a single isolate from cattle, six isolates from pigs, and three isolates from poultry. The floR gene was not detected (191). Among 116 avian-pathogenic E. coli isolates from chickens in Egypt, 98 (84.5\%) were resistant to chloramphenicol. The resistance genes catA1, cat $A 2$, and $c m l A$ were found in 86 , four, and eight isolates, respectively, while the genes cat $A 3$ and $\mathrm{cmlB}$ were not detected (192). Among 102 chloramphenicolresistant $E$. coli isolates from horses in the UK, 75 harbored the gene catA1. The remaining 27 isolates were PCR negative for the genes catA2, catA3, and cmlA, while the presence of the genes floR and $c f r$ was not tested (193). The cassette-borne chloramphenicol resistance genes catB3 and cmlA6 were identified in four and two canine $E$. coli isolates, respectively, all from the United States. The gene catB3 was located together with the resistance genes aacA4 and $d f r A 1$, and the gene cmlA6 was located together with the genes $a a d B$ and aadA1 in class 1 integrons of different sizes (194). In a study of $62 \mathrm{E}$. coli isolates from dogs in Iran, three isolates harbored the $\mathrm{cmlA}$ gene, whereas six isolates were positive for the floR gene (195). Among 36 chloramphenicol- and florfenicol-resistant E. coli isolates from dogs suffering from urinary tract infections in Taiwan, all isolates harbored the $\mathrm{cmlA}$ gene and 18 carried the floR gene (196). The $\mathrm{cmlA}$ gene was also 
detected in two chloramphenicol-resistant E. coli isolates from fecal samples of free-range Iberian lynx (143). Of $89 \mathrm{E}$. coli isolates from giant pandas, 28 and 23 were resistant to chloramphenicol and florfenicol, respectively. The floR gene was detected in 23 isolates and the $\mathrm{cmlA}$ gene in nine isolates, with two isolates carrying both genes. The $c f r$ gene was not detected in any of the isolates, and cat genes were not tested (128). The genes catA1 and cmlA were also detected in two and one multiresistant $E$. coli isolates, respectively, from shellfish in Vietnam (197).

The genes catA1, cmlA, and floR are often found on plasmids. In bovine E. coli from the United States, the floR gene was located on large plasmids of $225 \mathrm{~kb}(\underline{190})$, which were larger than those found in E. coli from sick chickens (198). Southern blot analysis confirmed the presence of the $\mathrm{cmlA}$ gene on plasmids of $>100 \mathrm{~kb}$ in E. coli from pigs (199). Conjugation assays identified two distinct class 1 integrons that linked $\mathrm{cmlA}$ to the streptomycin/spectinomycin resistance genes aadA1 and aadA2 and to the sulfonamide resistance genes sul1 or sul3 (199). Transformation experiments conducted with Canadian E. coli from pigs revealed that aadA and sul1 were located together with catA1 on a large ETEC plasmid (189). Plasmids that harbored the gene $\mathrm{cmlA}$ also carried the resistance genes aadA and sul3. Moreover, plasmids that harbored the genes $a a d B$ and $f l o R$ also carried sul2, tet $(\mathrm{A}), b l a_{\mathrm{CMY}-2}, \operatorname{str} A$, and $\operatorname{str} B$ but occasionally also aac(3)-IV (189). Among Brazilian E. coli from dogs, a $35-\mathrm{kb}$ IncF/IncFIB plasmid was identified that harbored the genes $\operatorname{str} A$ and $\operatorname{str} B$, and an unusual class 1 integron with the genes $d f r A 12$, aadA2, cmlA1, and aadA1 linked to a sul3 gene (185). The ca. $35-\mathrm{kb}$ plasmid pMBSF1 from porcine E. coli in Germany carried the floR gene together with the genes $s t r A$ and $s t r B$ (200). The floR gene was also detected on conjugative plasmids ranging in size from 110 to $125 \mathrm{~kb}$ from bovine E. coli in France. All these plasmids mediated additional resistances to sulfonamides, streptomycin, ampicillin, and/or trimethoprim (201). These examples show that phenicol resistance genes can also be coselected under the selective pressure imposed by nonphenicol antimicrobial agents.

The multiresistance gene $c f r$-originally identified in staphylococci of animal origin-was also found to be functionally active in E. coli (202). The gene $c f r$ was first reported in E. coli from a nasal swab of a pig in China (203). Later, it was identified on the 135,615-bp IncA/C multiresistance plasmid pSCEC2 from a pig in China. This plasmid also harbored the resistance genes sul2, tet(A), floR, strA, and $\operatorname{str} B$ (157). In another study in
China, the $c$ fr gene was detected on plasmids of ca. $30 \mathrm{~kb}$ in E. coli isolates from pigs (204). The complete sequence of the 37,672-bp plasmid pSD11, again from E. coli of porcine origin in China, was reported by Sun and colleagues (205). The colocation of $c f r$ with the ESBL gene $b l a_{\mathrm{CTX}-\mathrm{M}-14 \mathrm{~b}}$ on the 41,646-bp plasmid pGXEC3 from a porcine E. coli isolate was reported in 2015 (206). In the same year, another $c f r$-carrying plasmid, the conjugative 33,885-bp plasmid pFSEC-01, was reported (207). Although this plasmid was found in a porcine E. coli isolate, it closely resembled in its structure the plasmid pEA3 from the plant pathogen Erwinia amylovora. Most recently, another six cfr-carrying E. coli isolates-five from pigs and one from a chickenwere identified. In all cases, the $c f r$ gene was located as the only resistance gene on plasmids of either 37 or $67 \mathrm{~kb}$. Two of these plasmids were completely sequenced: the 37,663-bp IncX4 plasmid pEC14cfr and the 67,077-bp F14: $\mathrm{A}^{-}: \mathrm{B}^{-}$plasmid pEC29cfr (161).

\section{RESISTANCE TO SULFONAMIDES AND TRIMETHOPRIM}

Sulfonamides and trimethoprim are synthetic antimicrobial agents that inhibit different steps in the folic acid synthesis pathway. Each of these agents acts in a bacteriostatic manner, whereas the combination of a sulfonamide with trimethoprim results in synergistic bactericidal actions on susceptible organisms; as such, the combination is referred to as a "potentiated" sulfonamide. Sulfonamides and trimethoprim have been used for decades in animals and humans. Acquired resistance mechanisms have been frequently identified, mainly due to (i) mutational modifications in the genes encoding the target enzymes, namely, the dihydropteroate synthase or dihydrofolate reductase, respectively, or (ii) the acquisition of sul genes encoding dihydropteorate synthetases that are insensitive to sulfonamides or $d f r$ genes encoding dihydrofolate reductases that are insensitive to trimethoprim (208).

\section{Resistance to Sulfonamides}

In E. coli from food-producing and companion animals, sulfonamide resistance is mediated by any of the following three sul genes: sul1, sul2, or sul3. The sul1 gene is particularly widespread because it is part of the 3'-conserved segment of class 1 integrons (209). As such, the sul1 gene is often found together with other antimicrobial resistance genes that are located on gene cassettes in the variable part of class 1 integrons (209). Class 1 integrons are present in E. coli from healthy and 
diseased food-producing animals, companion animals, and wildlife all over the world as illustrated in the following examples. In Germany, 58 of 417 E. coli isolates from diseased swine, horses, dogs, and cats, collected in the BfT-GermVet monitoring study, harbored class 1 integrons (210). Other studies identified class 1 integrons in E. coli from healthy and diseased dogs in Brazil (185), in clinical avian E. coli isolates in the United States (211), in E. coli from lizards in Indonesia (212), in Shiga toxin-producing E. coli from cattle in the United States (213), in E. coli from free-range reindeer in Norway (214), in calf-pathogenic E. coli in China (215), in E. coli from pigs in Denmark (216), and even in E. coli from giant pandas in China (128). Class 1 integrons including the sul1 gene are often located on plasmids, including ESBL-gene-carrying multiresistance plasmids $(14,216-218)$.

The gene sul2 is also widely disseminated among E. coli of various animal species in different parts of the world. It has been found in E. coli from pigs in Canada (219) and Denmark (216), in food-producing animals in Kenya (220), in poultry in Nigeria (221) and Germany (222), and in horses in the Czech Republic (93). The sul2 gene is often linked to the streptomycin resistance genes strA-strB. Similarly to sul1, the sul2 gene is commonly found on plasmids that also harbor other antimicrobial resistance genes $(\underline{93}, \underline{157}, \underline{220}, 221, \underline{223})$.

The gene sul3 was first described in 2003 in E. coli isolates from pigs in Switzerland (224). Since then, this gene has been identified mostly on plasmids in E. coli from pigs in the United States (199), Canada (219), and Denmark (216); from poultry in Germany (222); and from dogs in Spain (138) and Brazil (185). Several reports described the sul3 gene to be linked to other resistance genes, such as the macrolide resistance gene $m e f(\mathrm{~B})(\underline{225})$, and to unusual class 1 integrons $(\underline{39}, \underline{185}$, 199, 226).

\section{Resistance to Trimethoprim}

Numerous $d f r$ genes that confer trimethoprim resistance have been detected in Enterobacteriaceae and other Gram-negative bacteria. Based on their sizes and structures, they have been divided into two major groups, $d f r A$ and $d f r B$ (227). The $d f r A$ genes code for proteins of 152 to 189 amino acids, while the $d f r B$-encoded proteins are only 78 amino acids in size. Most of the $d f_{r} A$ and $d f_{r} B$ genes found in E. coli of animal origin are located on gene cassettes that are inserted into class 1 or class 2 integrons. Some examples are given for $d f r A$ genes that have been identified in E. coli from $\operatorname{dogs}(d f r A 1$, $d f r A 12, d f r A 17, d f r A 29)(138,185,210)$, cats (dfrA1, $d f r A 12)(\underline{210})$, horses (dfrA1, dfrA9, dfrA12, dfrA17) $(\underline{193}, 210)$, pigs (dfrA1, dfrA5, dfrA8,dfrA12, dfrA13, $\left.d f_{r A 14} d f_{r A 16} d f_{r A 17}\right)(144,156,210,228,229)$, cattle (dfrA1, dfrA8,dfrA12,dfrA17) $(14,215,229)$, chickens (dfrA1, dfrA5, dfrA12, dfrA14, dfrA16) (144, 229), and giant pandas (dfrA1,dfrA7,dfrA12,dfrA17) (128). In contrast to $d f r A$ genes, $d f r B$ genes have rarely been detected in E. coli from animals. A $d f r B 4$ gene and a $d$ r $A 17$ gene were detected in class 1 integrons from sea lions (230). In the study by Seputiené et al. (229), the $d$ frA 8 gene was located in neither class 1 nor in class 2 integrons. Moreover, only seven of the $13 d f r A 14$ genes in E. coli isolates of animal origin were integronassociated. In previous studies of E. coli from foodproducing animals, a functionally active $d f r A 14$ gene was found outside an integron but inserted into a plasmid-borne strA gene (220, 231).

\section{RESISTANCE TO POLYMYXINS}

Colistin (also known as polymyxin E) is a polypeptide antimicrobial agent that targets the LPS in the outer membrane of Gram-negative bacteria (232). Colistin is widely used in veterinary medicine, mainly for the treatment or prevention of intestinal infections, particularly neonatal and postweaning diarrhea in pigs and intestinal infections in poultry and cattle (233). Very recently, due to the considerable concerns that colistin resistance might be transferable from animals to humans, specific regulations on the use of colistin have been set up in Europe under the umbrella of the European Medicines Agency (234). In April 2017, a ban of colistin as a growth promoter also became effective in China (235). Colistin is active against various species of Enterobacteriaceae, including E. coli, whereas others such as Proteus spp. and Serratia spp. are intrinsically resistant (232). Resistance to colistin can be due to mutations in chromosomal genes or to acquired resistance genes.

\section{Chromosome-Encoded Polymyxin Resistance}

Polymyxin resistance in E. coli isolates may be related to genes encoding LPS-modifying enzymes. The operon pmrCAB codes for three proteins, namely, a phosphoethanolamine phosphotransferase PmrC, a response regulator PmrA (also called BasR), and a sensor kinase protein PmrB (also called BasS) (232). Mutations either in PmrA or in PmrB have been found to be responsible for polymyxin resistance in E. coli isolates recovered from poultry in Spain (236). However, most of the mutations leading to polymyxin resistance in that op- 
eron or in others, such as the PhoPQ two-component system or its regulator $\mathrm{MgrB}$, have been identified in human E. coli isolates. Ongoing studies are being conducted to evaluate whether the same mechanisms might be responsible for polymyxin resistance in animal isolates. In one such study, mutations in the genes $p m r A$, $p m r B, m g r B$, $p h o P$, and $p h o Q$ of E. coli isolates from pigs were identified (237).

\section{Plasmid-Mediated Polymyxin Resistance}

In November 2016, the first plasmid-borne polymyxin resistance gene was identified. This gene was designated $m c r-1$, and it encodes the MCR-1 phosphoethanolamine transferase (238). Production of MCR-1 leads to the modification of the lipid A moiety of the LPS, resulting in a more cationic LPS and, consequently, to resistance to polymyxins. Production of MCR-1 in E. coli leads to a 4- to 8-fold increase in the MICs of polymyxins (232).

The $m c r-1$ gene has been detected mainly in E. coli isolates but also in other Enterobacteriaceae genera, such as Salmonella, Shigella, Klebsiella, and Enterobacter (239). This gene has now been identified worldwide, in both animal and human isolates. The $\mathrm{mcr}$ 1 gene has been found to be located on plasmids of various incompatibility groups (IncI2, IncHI2, IncP, IncX4, IncY, IncFI, and IncFIB) and variable sizes (58 to $251 \mathrm{~kb})(232)$. A few reports showed that it may be colocated with ESBL-encoding genes and/or other resistance genes $(71,240-244)$; nonetheless, most of the reports identified $m c r-1$ as the sole resistance gene on the respective plasmids. This may suggest that a polymyxinrelated selective pressure is responsible for the $m c r-1$ acquisition, with corresponding plasmids providing no other obvious selective advantage. Upstream of the $\mathrm{mcr}$ 1 gene, the ISApl1 insertion sequence element is frequently identified, although it is often, but not always, also identified downstream of it. Recent studies demonstrated that the mcr-1 gene is mobilized by transposition when bracketed by two copies of ISApl1 that form a composite transposon structure $(242,245)$. So far, 11 variants of the $m c r-1$ gene, designated $\mathrm{mcr}-1.2$ to $\mathrm{mcr}$ 1.12 have been identified, with $m c r-1.3$ being found in E. coli from chickens in China (246), $m c r-1.8$ in E. coli from poultry in Brunei (GenBank accession no. KY683842.1), $m c r-1.9$ in E. coli from swine in Portugal (KY964067.1), and mcr-1.12 in E. coli from pork in Japan (LC337668.1).

Recently, the plasmid-mediated colistin-resistance $m c r-2$ gene was identified in E. coli isolates recovered from piglets in Belgium (247). It shared $77 \%$ nucleotide sequence identity with $m c r-1$ and was located on an IncX4 plasmid. The $m c r-2$ gene has been sporadically identified so far (248). In addition, further $\mathrm{mcr}$ genes- $m c r-3$ to $m c r-7$-and variants thereof have been described. Among them, the $m c r-3$ gene was initially identified together with 18 additional resistance genes on the 261-kb IncHI2-type plasmid pWJ1 from porcine E. coli (249). The $m c r-3$ gene showed $45.0 \%$ and $47.0 \%$ nucleotide sequence identity to $m c r-1$ and $m c r-2$, respectively. So far, ten variants of $m c r-3$, designated $m c r-3.2$ to $m c r-3.11$, have been identified, with the $m c r$ 3.2 gene being originally detected in E. coli from cattle in Spain (250). A recent study in France reported the spread of a single E. coli clone harboring $\mathrm{mcr}$-3 in the veal calves sector from 2011 to 2016 (251). The combination in those isolates of $m c r-3$ and $b l a_{\text {CTX-M-55, }}$, an ESBL gene that is highly prevalent in Asian countries and rarely detected in Europe, may suggest the introduction and further dissemination of $m c r-3$ in that specific animal setting due to international trade. The $\mathrm{mcr}$-4 gene was detected among E. coli from pigs in Spain and Belgium that suffered from postweaning diarrhea (252). The gene $m c r-5$ and a variant, designated $m c r-5.2$, have recently been found in E. coli from pigs (253).

\section{Epidemiology of $\mathbf{m c r}-1$}

The $m c r-1$ gene is a resistance gene identified in human and animal E. coli isolates. Its occurrence in animal isolates is quite elevated (232), and it has been identified worldwide. MCR-1-producing E. coli isolates have been identified in several food-producing animals and meat, including chickens and chicken meat, pigs and piglets, cattle, calves, and turkeys (254, 255) (Table 4). Those isolates are from many Asian countries (Cambodia, China, Japan, Laos, Malaysia, Taiwan, Singapore, Vietnam, India, Pakistan, South Korea), from Europe (Belgium, Denmark, France, Germany, Portugal, Italy, the Netherlands, Spain, Sweden, Switzerland, the UK), the Americas (Argentina, Brazil, Canada, the U.S., Ecuador, Bolivia, Venezuela), Australia, and Africa (Algeria, Egypt, South Africa, Tunisia). Worryingly, a recent study performed in China identified a series of MCR-1-producing E. coli isolates recovered from poultry, with many of the isolates coproducing the carbapenemase NDM-1 (71). In addition, such multidrug-resistant isolates were recovered from flies and dogs present in the same farm environment, thus highlighting that those latter animals might also constitute sources of transmission (71). Additionally, some studies highlighted that $m c r$-1-positive $E$. coli may be also present in the environment or in food, being, for in- 
TABLE 4 Examples of acquired $m c r$ genes in E. coli of animal origin from Europe, North and South America, and Asia

\begin{tabular}{|c|c|c|c|c|}
\hline mor gene & $\begin{array}{l}\text { Geographical } \\
\text { origin }\end{array}$ & Source & Sequence type(s) & Reference \\
\hline \multirow[t]{13}{*}{$m c r-1$} & China & Pig & & $\underline{238}$ \\
\hline & China & Pig & & $\underline{242}$ \\
\hline & China & Pig & $\begin{array}{l}48,54,90,156,165,167,410,1114,1178,1437 \\
2439,3331,4429,4463,4656\end{array}$ & $\underline{277}$ \\
\hline & China & Poultry & $\begin{array}{c}10,48,58,77,88,101,117,178,215,361,501,542,616,617,648 \\
744,761,870,873,952,971,1290,1431,1642,2345,2491,2599 \\
3044,3133,3481,3944,5542,5815,5865,5879,5909,6050\end{array}$ & $\underline{246}$ \\
\hline & Vietnam & Reptiles & 117,1011 & $\underline{282}$ \\
\hline & South Korea & Poultry, pig & $1,10,88,101,156,162,226,410,1141,2732$ & $\underline{283}$ \\
\hline & Germany & Pig & $1,10,846$ & $\underline{240}$ \\
\hline & Germany & Pig (manure), fly, dog & $10,342,1011,5281$ & $\underline{256}$ \\
\hline & France & Cattle & & $\underline{241}$ \\
\hline & Italy & Poultry (meat) & 602 & $\underline{243}$ \\
\hline & U.S. & Pig & 132,3234 & $\underline{284}$ \\
\hline & Venezuela & Pig & 452 & $\underline{285}$ \\
\hline & Brazil & Magellanic penguin & 10 & $\underline{286}$ \\
\hline$m c r-1.3$ & China & Poultry & 155 & $\underline{246}$ \\
\hline$m c r-1.8$ & Brunei & Poultry & 101 & KY683842.1 \\
\hline$m c r-1.9$ & Portugal & Pig & & KY964067. $1^{\circ}$ \\
\hline$m c r-1.12$ & Japan & Pig & & LC337668.1 \\
\hline$m c r-2$ & Belgium & Pig, cattle & 10,167 & $\underline{247}$ \\
\hline \multirow[t]{2}{*}{$m c r-3$} & China & Pig & 1642 & $\underline{249}$ \\
\hline & France & Cattle & 744 & $\underline{251}$ \\
\hline$m c r-3.2$ & Spain & Cattle & 533 & $\underline{250}$ \\
\hline$m c r-4$ & Spain, Belgium & Pig & 10,7029 & $\underline{252}$ \\
\hline$m c r-5$ & Germany & Pig & 29,349 & $\underline{253}$ \\
\hline$m c r-5.2$ & Germany & Pig & 1494 & $\underline{253}$ \\
\hline
\end{tabular}

${ }^{a}$ GenBank accession number.

stance, identified in rivers but also in Asian imported vegetables in Switzerland (243). The environmental emission of MCR-1-producing and multiresistant E. coli isolates was recently stressed by studying the close surroundings of pig farms in Germany (256).

Dating the emergence of $m c r-1$-positive E. coli isolates remains difficult, although a Chinese study retrospectively identified $m c r$-1-positive isolates from chickens in the 1980s (255) and as early as 2005 in veal calves in France (254). It seems, therefore, that the emergence of $m c r$-positive isolates, at least in animals, is not a recent event. Very likely, there has been some silent dissemination of $\mathrm{mcr}$ genes through the past decades, and the current situation shows ongoing further dissemination rather than an emerging phenomenon.

\section{CONCLUSIONS}

Antimicrobial resistance in E. coli is an issue of the utmost importance since it occurs in both the human and animal sectors in a One Health perspective. In animals, multidrug resistance in E. coli may lead to difficult-totreat infections, but even more importantly, it constitutes a major and shared reservoir of resistance determinants to most families of antimicrobial agents across a vast number of animal species, including humans. Even though the different transmission pathways of resistant E. coli isolates from animals to humans remain to be clarified and their relative importance quantified, some data may support the role of the food chain since those bacteria have been demonstrated as common colonizers of foodstuffs at retail in many countries and continents. Other routes of transmission may include direct contacts with animals or indirect transfers through the environment. Since E. coli is a bacterium that is widely spread in all sectors, antimicrobial resistance in E. coli in animals has led to numerous cross-sectorial and joint initiatives, encompassing translational research, epidemiology, and surveillance in both human and veterinary medicine. It is now considered that the battle against the increased occurrence of antimicrobial resistance in E. coli from humans cannot be won without acting on a very large 
scale. To tone down some current and alarming speculations, and in view of all the studies that have been conducted during recent years, it is, however, likely that the occurrence of carbapenemase-producing E. coli in animals does not represent a significant threat for human health (31). In contrast, recent data have demonstrated that animals are very significant reservoirs of plasmidmediated colistin resistance genes-mostly present in E. coli isolates-which may represent a further risk for humans.

\section{ACKNOWLEDGMENTS}

This work was supported by the Swiss National Science Foundation (projects FNS-407240_177381 and 40AR40_173686) and by the University of Fribourg.

\section{REFERENCES}

1. Kaper JB, Nataro JP, Mobley HL. 2004. Pathogenic Escherichia coli. Nat Rev Microbiol 2:123-140 http://dx.doi.org/10.1038/nrmicro818.

2. Köhler CD, Dobrindt U. 2011. What defines extraintestinal pathogenic Escherichia coli? Int J Med Microbiol 301:642-647 http://dx.doi .org/10.1016/j.ijmm.2011.09.006.

3. Johnson JR, Russo TA. 2005. Molecular epidemiology of extraintestinal pathogenic (uropathogenic) Escherichia coli. Int J Med Microbiol 295:383-404 http://dx.doi.org/10.1016/j.ijmm.2005.07.005.

4. Izzo MM, Kirkland PD, Mohler VL, Perkins NR, Gunn AA, House JK. 2011. Prevalence of major enteric pathogens in Australian dairy calves with diarrhoea. Aust Vet J 89:167-173 http://dx.doi.org/10.1111/j.1751 -0813.2011.00692.x.

5. Kolenda R, Burdukiewicz M, Schierack P. 2015. A systematic review and meta-analysis of the epidemiology of pathogenic Escherichia coli of calves and the role of calves as reservoirs for human pathogenic E. coli. Front Cell Infect Microbiol 5:23 http://dx.doi.org/10.3389/fcimb.2015.00023.

6. Bouillon J, Snead E, Caswell J, Feng C, Hélie P, Lemetayer J. 2018. Pyelonephritis in dogs: retrospective study of 47 histologically diagnosed cases (2005-2015).J Vet Intern Med 32:249-259 http://dx.doi.org/10.1111 ljvim.14836.

7. Hutton TA, Innes GK, Harel J, Garneau P, Cucchiara A, Schifferli DM, Rankin SC. 2018. Phylogroup and virulence gene association with clinical characteristics of Escherichia coli urinary tract infections from dogs and cats. J Vet Diagn Invest 30:64-70 http://dx.doi.org/10.1177/104063871 7729395.

8. Antão EM, Glodde S, Li G, Sharifi R, Homeier T, Laturnus C, Diehl I, Bethe A, Philipp HC, Preisinger R, Wieler LH, Ewers C. 2008. The chicken as a natural model for extraintestinal infections caused by avian pathogenic Escherichia coli (APEC). Microb Pathog 45:361-369 http://dx.doi.org/10.1016/j.micpath.2008.08.005.

9. Ruegg PL. 2017. A 100-year review: mastitis detection, management, and prevention. J Dairy Sci 100:10381-10397 http://dx.doi.org/10.3168 ljds.2017-13023.

10. Taponen S, Liski E, Heikkilä AM, Pyörälä S. 2017. Factors associated with intramammary infection in dairy cows caused by coagulase-negative staphylococci, Staphylococcus aureus, Streptococcus uberis, Streptococcus dysgalactiae, Corynebacterium bovis, or Escherichia coli. J Dairy Sci 100:493-503 http://dx.doi.org/10.3168/jds.2016-11465.

11. Shpigel NY, Elazar S, Rosenshine I. 2008. Mammary pathogenic Escherichia coli. Curr Opin Microbiol 11:60-65 http://dx.doi.org/10.1016 j.mib.2008.01.004.

12. Suojala L, Kaartinen L, Pyörälä S. 2013. Treatment for bovine Escherichia coli mastitis: an evidence-based approach. J Vet Pharmacol Ther 36:521-531 http://dx.doi.org/10.1111/jvp.12057.
13. Dahmen S, Métayer V, Gay E, Madec JY, Haenni M. 2013. Characterization of extended-spectrum $\beta$-lactamase (ESBL)-carrying plasmids and clones of Enterobacteriaceae causing cattle mastitis in France. Vet Microbiol 162:793-799 http://dx.doi.org/10.1016/j.vetmic.2012.10 .015 .

14. Freitag C, Michael GB, Kadlec K, Hassel M, Schwarz S. 2017. Detection of plasmid-borne extended-spectrum $\beta$-lactamase (ESBL) genes in Escherichia coli isolates from bovine mastitis. Vet Microbiol 200:151-156 http://dx.doi.org/10.1016/j.vetmic.2016.08.010.

15. Su Y, Yu CY, Tsai Y, Wang SH, Lee C, Chu C. 2016. Fluoroquinoloneresistant and extended-spectrum $\beta$-lactamase-producing Escherichia coli from the milk of cows with clinical mastitis in southern Taiwan. J Microbiol Immunol Infect 49:892-901 http://dx.doi.org/10.1016/j.jmii.2014 $\underline{.10 .003 .}$.

16. Timofte D, Maciuca IE, Evans NJ, Williams H, Wattret A, Fick JC, Williams NJ. 2014. Detection and molecular characterization of Escherichia coli CTX-M-15 and Klebsiella pneumoniae SHV-12 $\beta$-lactamases from bovine mastitis isolates in the United Kingdom. Antimicrob Agents Chemother 58:789-794 http://dx.doi.org/10.1128/AAC.00752-13.

17. Pempek JA, Holder E, Proudfoot KL, Masterson M, Habing G. 2018. Short communication: investigation of antibiotic alternatives to improve health and growth of veal calves. J Dairy Sci 101:4473-4478 http://dx.doi .org/10.3168/jds.2017-14055.

18. Meganck V, Hoflack G, Opsomer G. 2014. Advances in prevention and therapy of neonatal dairy calf diarrhoea: a systematical review with emphasis on colostrum management and fluid therapy. Acta Vet Scand 56:75 http://dx.doi.org/10.1186/s13028-014-0075-x.

19. Dierikx CM, van der Goot JA, Smith HE, Kant A, Mevius DJ. 2013. Presence of ESBL/AmpC-producing Escherichia coli in the broiler production pyramid: a descriptive study. PLoS One 8:e79005 http://dx .doi.org/10.1371/journal.pone.0079005.

20. Haenni M, Châtre P, Métayer V, Bour M, Signol E, Madec JY, Gay E. 2014. Comparative prevalence and characterization of ESBL-producing Enterobacteriaceae in dominant versus subdominant enteric flora in veal calves at slaughterhouse, France. Vet Microbiol 171:321-327 http://dx .doi.org/10.1016/j.vetmic.2014.02.023.

21. Hordijk J, Mevius DJ, Kant A, Bos ME, Graveland H, Bosman AB, Hartskeerl CM, Heederik DJ, Wagenaar JA. 2013. Within-farm dynamics of ESBL/AmpC-producing Escherichia coli in veal calves: a longitudinal approach. J Antimicrob Chemother 68:2468-2476 http://dx.doi.org /10.1093/jac/dkt219.

22. Ambler RP. 1980. The structure of $\beta$-lactamases. Philos Trans R Soc Lond B Biol Sci 289:321-331 http://dx.doi.org/10.1098/rstb.1980.0049. 23. Bush K, Jacoby GA. 2010. Updated functional classification of B-lactamases. Antimicrob Agents Chemother 54:969-976 http://dx.doi .org/10.1128/AAC.01009-09.

24. Ewers C, Bethe A, Semmler T, Guenther S, Wieler LH. 2012. Extended-spectrum $\beta$-lactamase-producing and AmpC-producing Escherichia coli from livestock and companion animals, and their putative impact on public health: a global perspective. Clin Microbiol Infect 18: 646-655 http://dx.doi.org/10.1111/j.1469-0691.2012.03850.x.

25. Madec JY, Haenni M, Nordmann P, Poirel L. 2017. Extendedspectrum $\beta$-lactamase/AmpC- and carbapenemase-producing Enterobacteriaceae in animals: a threat for humans? Clin Microbiol Infect 23: 826-833 http://dx.doi.org/10.1016/i.cmi.2017.01.013.

26. Hordijk J, Schoormans A, Kwakernaak M, Duim B, Broens E, Dierikx C, Mevius D, Wagenaar JA. 2013. High prevalence of fecal carriage of extended spectrum $\beta$-lactamase/AmpC-producing Enterobacteriaceae in cats and dogs. Front Microbiol 4:242-247 http://dx.doi.org/10.3389 /fmicb.2013.00242.

27. Lalak A, Wasyl D, Zając M, Skarżyńska M, Hoszowski A, Samcik I, Woźniakowski G, Szulowski K. 2016. Mechanisms of cephalosporin resistance in indicator Escherichia coli isolated from food animals. Vet Microbiol 194:69-73 http://dx.doi.org/10.1016/j.vetmic.2016.01.023. 
28. Schaufler K, Bethe A, Lübke-Becker A, Ewers C, Kohn B, Wieler LH, Guenther S. 2015. Putative connection between zoonotic multiresistant extended-spectrum $\beta$-lactamase (ESBL)-producing Escherichia coli in dog feces from a veterinary campus and clinical isolates from dogs. Infect Ecol Epidemiol 5:25334-25339 http://dx.doi.org/10.3402/iee.v5.25334.

29. Tian GB, Wang HN, Zhang AY, Zhang Y, Fan WQ, Xu CW, Zeng B, Guan ZB, Zou LK. 2012. Detection of clinically important $\beta$-lactamases in commensal Escherichia coli of human and swine origin in western China. J Med Microbiol 61:233-238 http://dx.doi.org/10.1099/jmm.0.036806-0. 30. Guenther S, Ewers C, Wieler LH. 2011. Extended-spectrum $\beta$-lactamases producing E. coli in wildlife, yet another form of environmental pollution? Front Microbiol 2:246-259 http://dx.doi.org/10.3389 /fmicb.2011.00246.

31. Karim A, Poirel L, Nagarajan S, Nordmann P. 2001. Plasmidmediated extended-spectrum $\beta$-lactamase (CTX-M-3 like) from India and gene association with insertion sequence ISEcp1. FEMS Microbiol Lett 201:237-241 https://doi.org/10.1111/j.1574-6968.2001.tb10762.x.

32. Pitout JD, Nordmann P, Laupland KB, Poirel L. 2005. Emergence of Enterobacteriaceae producing extended-spectrum $\beta$-lactamases (ESBLs) in the community. J Antimicrob Chemother 56:52-59 http://dx.doi.org /10.1093/jac/dki166.

33. Michael GB, Freitag C, Wendlandt S, Eidam C, Feßler AT, Lopes GV, Kadlec K, Schwarz S. 2015. Emerging issues in antimicrobial resistance of bacteria from food-producing animals. Future Microbiol 10:427-443 http://dx.doi.org/10.2217/fmb.14.93.

34. EFSA. 2011. Panel on Biological Hazards (BIOHAZ); scientific opinion on the public health risks of bacterial strains producing extendedspectrum $\beta$-lactamases and/or AmpC $\beta$-lactamases in food and foodproducing animals. EFSA J 9:2322-2417 http://dx.doi.org/10.2903/j.efsa .2011 .2322 .

35. Michael GB, Kaspar H, Siqueira AK, de Freitas Costa E, Corbellini LG, Kadlec K, Schwarz S. 2017. Extended-spectrum $\beta$-lactamase (ESBL)producing Escherichia coli isolates collected from diseased food-producing animals in the GERM-Vet monitoring program 2008-2014. Vet Microbiol 200:142-150 http://dx.doi.org/10.1016/j.vetmic.2016.08.023.

36. Day MJ, Rodríguez I, van Essen-Zandbergen A, Dierikx C, Kadlec K, Schink AK, Wu G, Chattaway MA, DoNascimento V, Wain J, Helmuth R, Guerra B, Schwarz S, Threlfall J, Woodward MJ, Coldham N, Mevius D, Woodford N. 2016. Diversity of STs, plasmids and ESBL genes among Escherichia coli from humans, animals and food in Germany, the Netherlands and the UK. J Antimicrob Chemother 71:1178-1182 http:// dx.doi.org/10.1093/jac/dkv485.

37. Schmiedel J, Falgenhauer L, Domann E, Bauerfeind R, PrengerBerninghoff E, Imirzalioglu C, Chakraborty T. 2014. Multiresistant extended-spectrum $\beta$-lactamase-producing Enterobacteriaceae from humans, companion animals and horses in central Hesse, Germany. BMC Microbiol 14:187-200 http://dx.doi.org/10.1186/1471-2180-14-187.

38. Shaheen BW, Nayak R, Foley SL, Kweon O, Deck J, Park M, Rafii F, Boothe DM. 2011. Molecular characterization of resistance to extendedspectrum cephalosporins in clinical Escherichia coli isolates from companion animals in the United States. Antimicrob Agents Chemother 55: 5666-5675 http://dx.doi.org/10.1128/AAC.00656-11.

39. Alonso CA, Michael GB, Li J, Somalo S, Simón C, Wang Y, Kaspar H, Kadlec K, Torres C, Schwarz S. 2017. Analysis of bla $a_{\mathrm{SHV}-12-c a r r y i n g}$ Escherichia coli clones and plasmids from human, animal and food sources. J Antimicrob Chemother 72:1589-1596 http://dx.doi.org/10.1093/jac /dkx024.

40. Peirano G, Pitout JD. 2010. Molecular epidemiology of Escherichia coli producing CTX-M beta-lactamases: the worldwide emergence of clone ST131 O25:H4. Int J Antimicrob Agents 35:316-321 http://dx.doi .org/10.1016/j.ijantimicag.2009.11.003.

41. Albrechtova K, Dolejska M, Cizek A, Tausova D, Klimes J, Bebora L, Literak I. 2012. Dogs of nomadic pastoralists in northern Kenya are reservoirs of plasmid-mediated cephalosporin- and quinolone-resistant
Escherichia coli, including pandemic clone B2-O25-ST131. Antimicrob Agents Chemother 56:4013-4017 http://dx.doi.org/10.1128/AAC.05859-11. 42. Marques C, Belas A, Franco A, Aboim C, Gama LT, Pomba C. 2018 Increase in antimicrobial resistance and emergence of major international high-risk clonal lineages in dogs and cats with urinary tract infection: 16 year retrospective study. J Antimicrob Chemother 73:377-384 http:// dx.doi.org/10.1093/jac/dkx401.

43. Schink AK, Kadlec K, Kaspar H, Mankertz J, Schwarz S. 2013. Analysis of extended-spectrum- $\beta$-lactamase-producing Escherichia coli isolates collected in the GERM-Vet monitoring programme. J Antimicrob Chemother 68:1741-1749 http://dx.doi.org/10.1093/jac/dkt123.

44. Wieler LH, Ewers C, Guenther S, Walther B, Lübke-Becker A. 2011. Methicillin-resistant staphylococci (MRS) and extended-spectrum $\beta$-lactamases (ESBL)-producing Enterobacteriaceae in companion animals: nosocomial infections as one reason for the rising prevalence of these potential zoonotic pathogens in clinical samples. Int J Med Microbiol 301:635-641 http://dx.doi.org/10.1016/j.ijmm.2011.09.009.

45. Cantón R, González-Alba JM, Galán JC. 2012. CTX-M enzymes: origin and diffusion. Front Microbiol 3:110-129 http://dx.doi.org /10.3389/fmicb.2012.00110

46. Poirel L, Naas T, Nordmann P. 2008. Genetic support of extendedspectrum $\beta$-lactamases. Clin Microbiol Infect 14(Suppl 1):75-81 http://dx .doi.org/10.1111/j.1469-0691.2007.01865.x.

47. Carattoli A. 2013. Plasmids and the spread of resistance. Int J Med Microbiol 303:298-304 http://dx.doi.org/10.1016/j.ijmm.2013.02.001.

48. Ferreira JC, Penha Filho RA, Andrade LN, Berchieri A Jr, Darini AL. 2014. Detection of chromosomal bla ( (CTX-M-2) in diverse Escherichia coli isolates from healthy broiler chickens. Clin Microbiol Infect 20:O623O626 http://dx.doi.org/10.1111/1469-0691.12531.

49. Guenther S, Semmler T, Stubbe A, Stubbe M, Wieler LH, Schaufler K. 2017. Chromosomally encoded ESBL genes in Escherichia coli of ST38 from Mongolian wild birds. J Antimicrob Chemother 72:1310-1313 http://dx.doi.org/10.1093/jac/dkx006.

50. Valentin L, Sharp H, Hille K, Seibt U, Fischer J, Pfeifer Y, Michael GB, Nickel S, Schmiedel J, Falgenhauer L, Friese A, Bauerfeind R, Roesler U, Imirzalioglu C, Chakraborty T, Helmuth R, Valenza G, Werner G, Schwarz S, Guerra B, Appel B, Kreienbrock L, Käsbohrer A. 2014. Subgrouping of ESBL-producing Escherichia coli from animal and human sources: an approach to quantify the distribution of ESBL types between different reservoirs. Int J Med Microbiol 304:805-816 http://dx.doi.org/10.1016 j.ijmm.2014.07.015.

51. Wu G, Day MJ, Mafura MT, Nunez-Garcia J, Fenner JJ, Sharma M, van Essen-Zandbergen A, Rodríguez I, Dierikx C, Kadlec K, Schink AK, Chattaway M, Wain J, Helmuth R, Guerra B, Schwarz S, Threlfall J, Woodward MJ, Woodford N, Coldham N, Mevius D. 2013. Comparative analysis of ESBL-positive Escherichia coli isolates from animals and humans from the UK, The Netherlands and Germany. PLoS One 8: e75392-e75402 http://dx.doi.org/10.1371/journal.pone.0075392.

52. Leverstein-van Hall MA, Dierikx CM, Cohen Stuart J, Voets GM, van den Munckhof MP, van Essen-Zandbergen A, Platteel T, Fluit AC, van de Sande-Bruinsma N, Scharinga J, Bonten MJ, Mevius DJ, National ESBL Surveillance Group. 2011. Dutch patients, retail chicken meat and poultry share the same ESBL genes, plasmids and strains. Clin Microbiol Infect 17:873-880 http://dx.doi.org/10.1111/j.1469-0691.2011.03497.x.

53. Casella T, Nogueira MCL, Saras E, Haenni M, Madec JY. 2017. High prevalence of ESBLs in retail chicken meat despite reduced use of antimicrobials in chicken production, France. Int J Food Microbiol 257:271-275 http://dx.doi.org/10.1016/j.ijfoodmicro.2017.07.005.

54. Jacoby GA. 2009. AmpC $\beta$-lactamases. Clin Microbiol Rev 22:161182 http://dx.doi.org/10.1128/CMR.00036-08.

55. Philippon A, Arlet G, Jacoby GA. 2002. Plasmid-determined AmpCtype $\beta$-lactamases. Antimicrob Agents Chemother 46:1-11 http://dx.doi .org/10.1128/AAC.46.1.1-11.2002. 
56. Liebana E, Carattoli A, Coque TM, Hasman H, Magiorakos AP, Mevius D, Peixe L, Poirel L, Schuepbach-Regula G, Torneke K, TorrenEdo J, Torres C, Threlfall J. 2013. Public health risks of enterobacterial isolates producing extended-spectrum $\beta$-lactamases or AmpC $\beta$-lactamases in food and food-producing animals: an EU perspective of epidemiology, analytical methods, risk factors, and control options. Clin Infect Dis 56: 1030-1037 http://dx.doi.org/10.1093/cid/cis1043.

57. Hansen KH, Bortolaia V, Nielsen CA, Nielsen JB, Schønning K, Agersø Y, Guardabassi L. 2016. Host-specific patterns of genetic diversity among IncI1-Igamma and IncK plasmids encoding CMY-2 $\beta$-lactamase in Escherichia coli isolates from humans, poultry meat, poultry, and dogs in Denmark. Appl Environ Microbiol 82:4705-4714 http://dx.doi.org 110.1128/AEM.00495-16.

58. Börjesson S, Ny S, Egervärn M, Bergström J, Rosengren Å, Englund S, Löfmark S, Byfors S. 2016. Limited dissemination of extended-spectrum $\beta$-lactamase- and plasmid-encoded AmpC-producing Escherichia coli from food and farm animals, Sweden. Emerg Infect Dis 22:634-640 http://dx.doi.org/10.3201/eid2204.151142.

59. Nilsson O, Börjesson S, Landén A, Bengtsson B. 2014. Vertical transmission of Escherichia coli carrying plasmid-mediated AmpC (pAmpC) through the broiler production pyramid. J Antimicrob Chemother 69: 1497-1500 http://dx.doi.org/10.1093/jac/dku030.

60. Loncaric I, Stalder GL, Mehinagic K, Rosengarten R, Hoelzl F, Knauer F, Walzer C. 2013. Comparison of ESBL-and AmpC producing Enterobacteriaceae and methicillin-resistant Staphylococcus aureus (MRSA) isolated from migratory and resident population of rooks (Corvus frugilegus) in Austria. PLoS One 8:e84048 http://dx.doi.org /10.1371/journal.pone.0084048.

61. Poirel L, Potron A, De La Cuesta C, Cleary T, Nordmann P, Munoz-Price LS. 2012. Wild coastline birds as reservoirs of broadspectrum- $\beta$-lactamase-producing Enterobacteriaceae in Miami Beach, Florida. Antimicrob Agents Chemother 56:2756-2758 http://dx.doi.org 10.1128/AAC.05982-11.

62. Báez J, Hernández-García M, Guamparito C, Díaz S, Olave A, Guerrero K, Cantón R, Baquero F, Gahona J, Valenzuela N, Del Campo R, Silva J. 2015. Molecular characterization and genetic diversity of ESBL-producing Escherichia coli colonizing the migratory Franklin's gulls (Leucophaeus pipixcan) in Antofagasta, North of Chile. Microb Drug Resist 21:111-116 http://dx.doi.org/10.1089/mdr.2014.0158.

63. Simões RR, Poirel L, Da Costa PM, Nordmann P. 2010. Seagulls and beaches as reservoirs for multidrug-resistant Escherichia coli. Emerg Infect Dis 16:110-112 http://dx.doi.org/10.3201/eid1601.090896.

64. Köck R, Daniels-Haardt I, Becker K, Mellmann A, Friedrich AW, Mevius D, Schwarz S, Jurke A. 2018. Carbapenem-resistant Enterobacteriaceae in wildlife, food-producing, and companion animals: a systematic review. Clin Microbiol Infect. Epub ahead of print. doi:10.1016 j.cmi.2018.04.004.

65. Poirel L, Stephan R, Perreten V, Nordmann P. 2014. The carbapenemase threat in the animal world: the wrong culprit. $J$ Antimicrob Chemother 69:2007-2008 http://dx.doi.org/10.1093/jac/dku054.

66. Woodford N, Wareham DW, Guerra B, Teale C. 2014. Carbapenemaseproducing Enterobacteriaceae and non-Enterobacteriaceae from animals and the environment: an emerging public health risk of our own making? J Antimicrob Chemother 69:287-291 http://dx.doi.org/10.1093 ljac/dkt392.

67. Fischer J, San José M, Roschanski N, Schmoger S, Baumann B, Irrgang A, Friese A, Roesler U, Helmuth R, Guerra B. 2017. Spread and persistence of VIM-1 carbapenemase-producing Enterobacteriaceae in three German swine farms in 2011 and 2012. Vet Microbiol 200:118-123 http://dx.doi.org/10.1016/j.vetmic.2016.04.026.

68. Fischer J, Rodríguez I, Schmoger S, Friese A, Roesler U, Helmuth R, Guerra B. 2012. Escherichia coli producing VIM-1 carbapenemase isolated on a pig farm. J Antimicrob Chemother 67:1793-1795 http://dx.doi .org/10.1093/jac/dks108.
69. Guerra B, Fischer J, Helmuth R. 2014. An emerging public health problem: acquired carbapenemase-producing microorganisms are present in food-producing animals, their environment, companion animals and wild birds. Vet Microbiol 171:290-297 http://dx.doi.org/10.1016/j .vetmic.2014.02.001.

70. Shaheen BW, Nayak R, Boothe DM. 2013. Emergence of a New Delhi metallo- $\beta$-lactamase (NDM-1)-encoding gene in clinical Escherichia coli isolates recovered from companion animals in the United States. Antimicrob Agents Chemother 57:2902-2903 http://dx.doi.org/10.1128/AAC $.02028-12$

71. Wang Y, Zhang R, Li J, Wu Z, Yin W, Schwarz S, Tyrrell JM, Zheng Y, Wang S, Shen Z, Liu Z, Liu J, Lei L, Li M, Zhang Q, Wu C, Zhang Q, Wu Y, Walsh TR, Shen J. 2017. Comprehensive resistome analysis reveals the prevalence of NDM and MCR-1 in Chinese poultry production. Nat Microbiol 2:16260 http://dx.doi.org/10.1038/nmicrobiol .2016 .260

72. Liu Z, Wang Y, Walsh TR, Liu D, Shen Z, Zhang R, Yin W, Yao H, Li J, Shen J. 2017. Plasmid-mediated novel bla $a_{\mathrm{NDM}-17}$ gene encoding a carbapenemase with enhanced activity in a sequence type 48 Escherichia coli strain. Antimicrob Agents Chemother 61:e02233-16.

73. Singh AS, Lekshmi M, Nayak BB, Kumar SH. 2016. Isolation of Escherichia coli harboring bla NDM-s from fresh fish in India. I Microbiol Immunol Infect 49:822-823 http://dx.doi.org/10.1016/j.jmii.2014.11.004.

74. Yang RS, Feng Y, Lv XY, Duan JH, Chen J, Fang LX, Xia J, Liao XP, Sun J, Liu YH. 2016. Emergence of NDM-5- and MCR-1-producing Escherichia coli clones ST648 and ST156 from a single Muscovy duck (Cairina moschata). Antimicrob Agents Chemother 60:6899-6902 http://dx.doi.org/10.1128/AAC.01365-16.

75. Yousfi M, Touati A, Mairi A, Brasme L, Gharout-Sait A, Guillard T, De Champs C. 2016. Emergence of carbapenemase-producing Escherichia coli isolated from companion animals in Algeria. Microb Drug Resist 22:342-346 http://dx.doi.org/10.1089/mdr.2015.0196.

76. Dolejska M, Masarikova M, Dobiasova H, Jamborova I, Karpiskova R, Havlicek M, Carlile N, Priddel D, Cizek A, Literak I. 2016. High prevalence of Salmonella and IMP-4-producing Enterobacteriaceae in the silver gull on Five Islands, Australia. J Antimicrob Chemother 71:63-70 http://dx.doi.org/10.1093/jac/dkv306.

77. Al Bayssari C, Olaitan AO, Dabboussi F, Hamze M, Rolain JM. 2015. Emergence of OXA-48-producing Escherichia coli clone ST38 in fowl. Antimicrob Agents Chemother 59:745-746 http://dx.doi.org/10.1128 IAAC.03552-14.

78. Melo LC, Boisson MN, Saras E, Médaille C, Boulouis HJ, Madec JY, Haenni M. 2017. OXA-48-producing ST372 Escherichia coli in a French dog. J Antimicrob Chemother 72:1256-1258.

79. Stolle I, Prenger-Berninghoff E, Stamm I, Scheufen S, Hassdenteufel E, Guenther S, Bethe A, Pfeifer Y, Ewers C. 2013. Emergence of OXA-48 carbapenemase-producing Escherichia coli and Klebsiella pneumoniae in dogs. J Antimicrob Chemother 68:2802-2808 http://dx.doi.org/10.1093 /jac/dkt259.

80. Pulss S, Semmler T, Prenger-Berninghoff E, Bauerfeind R, Ewers C. 2017. First report of an Escherichia coli strain from swine carrying an OXA-181 carbapenemase and the colistin resistance determinant MCR-1. Int J Antimicrob Agents 50:232-236 http://dx.doi.org/10.1016 ji.ijantimicag.2017.03.014.

81. Mollenkopf DF, Stull JW, Mathys DA, Bowman AS, Feicht SM, Grooters SV, Daniels JB, Wittum TE. 2017. Carbapenemase-producing Enterobacteriaceae recovered from the environment of a swine farrow-tofinish operation in the United States. Antimicrob Agents Chemother 61: e01298-16 http://dx.doi.org/10.1128/AAC.01298-16.

82. Munoz-Price LS, Poirel L, Bonomo RA, Schwaber MJ, Daikos GL, Cormican M, Cornaglia G, Garau J, Gniadkowski M, Hayden MK, Kumarasamy K, Livermore DM, Maya JJ, Nordmann P, Patel JB, Paterson DL, Pitout J, Villegas MV, Wang H, Woodford N, Quinn JP. 2013. Clinical epidemiology of the global expansion of Klebsiella pneu- 
moniae carbapenemases. Lancet Infect Dis 13:785-796 http://dx.doi.org /10.1016/S1473-3099(13)70190-7.

83. Hopkins KL, Davies RH, Threlfall EJ. 2005. Mechanisms of quinolone resistance in Escherichia coli and Salmonella: recent developments. Int J Antimicrob Agents 25:358-373 http://dx.doi.org/10.1016 /j.ijantimicag.2005.02.006.

84. de Jong A, Muggeo A, El Garch F, Moyaert H, de Champs C, Guillard T. 2018. Characterization of quinolone resistance mechanisms in Enterobacteriaceae isolated from companion animals in Europe (ComPath II study). Vet Microbiol 216:159-167 http://dx.doi.org/10.1016/j.vetmic .2018 .02 .002 .

85. Schink AK, Kadlec K, Hauschild T, Brenner Michael G, Dörner JC, Ludwig C, Werckenthin C, Hehnen HR, Stephan B, Schwarz S. 2013. Susceptibility of canine and feline bacterial pathogens to pradofloxacin and comparison with other fluoroquinolones approved for companion animals. Vet Microbiol 162:119-126 http://dx.doi.org/10.1016/j.vetmic .2012 .08 .001 .

86. Liu BT, Liao XP, Yang SS, Wang XM, Li LL, Sun J, Yang YR, Fang LX, Li L, Zhao DH, Liu YH. 2012. Detection of mutations in the gyrA and parC genes in Escherichia coli isolates carrying plasmid-mediated quinolone resistance genes from diseased food-producing animals. J Med Microbiol 61:1591-1599 http://dx.doi.org/10.1099/jmm.0.043307-0.

87. Redgrave LS, Sutton SB, Webber MA, Piddock LJ. 2014. Fluoroquinolone resistance: mechanisms, impact on bacteria, and role in evolutionary success. Trends Microbiol 22:438-445 http://dx.doi.org/10.1016 /j.tim.2014.04.007.

88. Cattoir V, Nordmann P. 2009. Plasmid-mediated quinolone resistance in Gram-negative bacterial species: an update. Curr Med Chem 16:10281046 http://dx.doi.org/10.2174/092986709787581879.

89. Rodríguez-Martínez JM, Machuca J, Cano ME, Calvo J, MartínezMartínez L, Pascual A. 2016. Plasmid-mediated quinolone resistance: two decades on. Drug Resist Updat 29:13-29 http://dx.doi.org/10.1016 /j.drup.2016.09.001.

90. Ma J, Zeng Z, Chen Z, Xu X, Wang X, Deng Y, Lü D, Huang L, Zhang Y, Liu J, Wang M. 2009. High prevalence of plasmid-mediated quinolone resistance determinants $q n r$, aac $\left(6^{\prime}\right)-I b-c r$, and $q e p A$ among ceftiofur-resistant Enterobacteriaceae isolates from companion and foodproducing animals. Antimicrob Agents Chemother 53:519-524 http://dx .doi.org/10.1128/AAC.00886-08.

91. Huang SY, Dai L, Xia LN, Du XD, Qi YH, Liu HB, Wu CM, Shen JZ. 2009. Increased prevalence of plasmid-mediated quinolone resistance determinants in chicken Escherichia coli isolates from 2001 to 2007. Foodborne Pathog Dis 6:1203-1209 http://dx.doi.org/10.1089 /fpd.2009.0348.

92. Veldman K, Cavaco LM, Mevius D, Battisti A, Franco A, Botteldoorn N, Bruneau M, Perrin-Guyomard A, Cerny T, De Frutos Escobar C, Guerra B, Schroeter A, Gutierrez M, Hopkins K, Myllyniemi AL, Sunde M, Wasyl D, Aarestrup FM. 2011. International collaborative study on the occurrence of plasmid-mediated quinolone resistance in Salmonella enterica and Escherichia coli isolated from animals, humans, food and the environment in 13 European countries. J Antimicrob Chemother 66: 1278-1286 http://dx.doi.org/10.1093/jac/dkr084.

93. Dolejska M, Duskova E, Rybarikova J, Janoszowska D, Roubalova E, Dibdakova K, Maceckova G, Kohoutova L, Literak I, Smola J, Cizek A. 2011. Plasmids carrying bla $a_{\mathrm{CTX}-\mathrm{M}-1}$ and $q n r$ genes in Escherichia coli isolates from an equine clinic and a horseback riding centre. J Antimicrob Chemother 66:757-764 http://dx.doi.org/10.1093/jac/dkq500.

94. Schink AK, Kadlec K, Schwarz S. 2012. Detection of qnr genes among Escherichia coli isolates of animal origin and complete sequence of the conjugative qnrB19-carrying plasmid pQNR2078. J Antimicrob Chemother 67:1099-1102 http://dx.doi.org/10.1093/jac/dks024.

95. Hordijk J, Bosman AB, van Essen-Zandbergen A, Veldman K, Dierikx C, Wagenaar JA, Mevius D. 2011. qnrB19 gene bracketed by IS26 on a 40-kilobase IncR plasmid from an Escherichia coli isolate from a veal calf.
Antimicrob Agents Chemother 55:453-454 http://dx.doi.org/10.1128 IAAC.00866-10.

96. Ewers C, Bethe A, Stamm I, Grobbel M, Kopp PA, Guerra B, Stubbe M, Doi Y, Zong Z, Kola A, Schaufler K, Semmler T, Fruth A, Wieler LH, Guenther S. 2014. CTX-M-15-D-ST648 Escherichia coli from companion animals and horses: another pandemic clone combining multiresistance and extraintestinal virulence? J Antimicrob Chemother 69:1224-1230 http://dx.doi.org/10.1093/jac/dkt516.

97. Liu X, Liu H, Li Y, Hao C. 2016. High prevalence of $\beta$-lactamase and plasmid-mediated quinolone resistance genes in extended-spectrum cephalosporin-resistant Escherichia coli from dogs in Shaanxi, China. Front Microbiol 7:1843-1852 http://dx.doi.org/10.3389/fmicb.2016 .01843 .

98. Pomba C, da Fonseca JD, Baptista BC, Correia JD, MartínezMartínez L. 2009. Detection of the pandemic O25-ST131 human virulent Escherichia coli CTX-M-15-producing clone harboring the qnrB2 and aac (6')-Ib-cr genes in a dog. Antimicrob Agents Chemother 53:327-328 http://dx.doi.org/10.1128/AAC.00896-08.

99. Timofte D, Maciuca IE, Williams NJ, Wattret A, Schmidt V. 2016. Veterinary hospital dissemination of CTX-M-15 extended-spectrum $\beta$-lactamase-producing Escherichia coli ST410 in the United Kingdom. Microb Drug Resist 22:609-615 http://dx.doi.org/10.1089/mdr.2016 .0036 .

100. Madec JY, Poirel L, Saras E, Gourguechon A, Girlich D, Nordmann P, Haenni M. 2012. Non-ST131 Escherichia coli from cattle harbouring human-like bla( (СтХ-м-15)-carrying plasmids. J Antimicrob Chemother 67:578-581 http://dx.doi.org/10.1093/jac/dkr542.

101. Chen X, He L, Li Y, Zeng Z, Deng Y, Liu Y, Liu JH. 2014. Complete sequence of a F2:A-:B- plasmid pHN3A11 carrying $r m t B$ and qepA, and its dissemination in China. Vet Microbiol 174:267-271 http://dx.doi.org /10.1016/j.vetmic.2014.08.023.

102. Liu BT, Yang QE, Li L, Sun J, Liao XP, Fang LX, Yang SS, Deng H, Liu YH. 2013. Dissemination and characterization of plasmids carrying oqxAB-bla CTX-M genes in Escherichia coli isolates from food-producing animals. PLoS One 8:e73947 http://dx.doi.org/10.1371/journal.pone .0073947 .

103. Hansen LH, Jensen LB, Sørensen HI, Sørensen SJ. 2007. Substrate specificity of the OqxAB multidrug resistance pump in Escherichia coli and selected enteric bacteria. J Antimicrob Chemother 60:145-147 http://dx.doi.org/10.1093/jac/dkm167.

104. Davies J, Wright GD. 1997. Bacterial resistance to aminoglycoside antibiotics. Trends Microbiol 5:234-240 http://dx.doi.org/10.1016/S0966 -842X(97)01033-0.

105. Doi Y, Wachino JI, Arakawa Y. 2016. Aminoglycoside resistance: the emergence of acquired 16S ribosomal RNA methyltransferases. Infect Dis Clin North Am 30:523-537 http://dx.doi.org/10.1016/j.idc.2016 .02 .011 .

106. Anonymous. 2014. Concept paper on the of aminoglycosides in animals in the European Union: development of resistance and impact on human and animal health. EMA/CVMP/AWP/158821/2014 1-4.

107. Fourmy D, Yoshizawa S, Puglisi JD. 1998. Paromomycin binding induces a local conformational change in the A-site of $16 \mathrm{~S}$ rRNA. J Mol Biol 277:333-345 http://dx.doi.org/10.1006/jmbi.1997.1551.

108. Bowers DR SAN, Tam VH. 2016. Aminoglycoside pharmacodynamics, p 199-220. In Rotschafer J, Andes D, Rodvold K (ed), Antibiotic Pharmacodynamics. Methods in Pharmacology and Toxicology. Humana Press, New York, NY.

109. Griffey RH, Hofstadler SA, Sannes-Lowery KA, Ecker DJ, Crooke ST. 1999. Determinants of aminoglycoside-binding specificity for rRNA by using mass spectrometry. Proc Natl Acad Sci USA 96:10129-10133 http://dx.doi.org/10.1073/pnas.96.18.10129.

110. Llano-Sotelo B, Hickerson RP, Lancaster L, Noller HF, Mankin AS. 2009. Fluorescently labeled ribosomes as a tool for analyzing antibiotic binding. RNA 15:1597-1604 http://dx.doi.org/10.1261/rna.1681609. 
111. Galimand M, Courvalin P, Lambert T. 2003. Plasmid-mediated high-level resistance to aminoglycosides in Enterobacteriaceae due to $16 \mathrm{~S}$ rRNA methylation. Antimicrob Agents Chemother 47:2565-2571 http://dx.doi.org/10.1128/AAC.47.8.2565-2571.2003.

112. Batah R, Loucif L, Olaitan AO, Boutefnouchet N, Allag H, Rolain JM. 2015. Outbreak of Serratia marcescens coproducing ArmA and CTX-M-15 mediated high levels of resistance to aminoglycoside and extended-spectrum $\beta$-lactamases, Algeria. Microb Drug Resist 21:470476 http://dx.doi.org/10.1089/mdr.2014.0240.

113. Dolejska M, Villa L, Poirel L, Nordmann P, Carattoli A. 2013. Complete sequencing of an IncHI1 plasmid encoding the carbapenemase NDM-1, the ArmA 16S RNA methylase and a resistance-nodulation-cell division/multidrug efflux pump. J Antimicrob Chemother 68:34-39 http:// dx.doi.org/10.1093/jac/dks357.

114. Gurung M, Moon DC, Tamang MD, Kim J, Lee YC, Seol SY, Cho DT, Lee JC. 2010. Emergence of $16 \mathrm{~S}$ rRNA methylase gene armA and cocarriage of bla (IMP-1) in Pseudomonas aeruginosa isolates from South Korea. Diagn Microbiol Infect Dis 68:468-470 http://dx.doi.org 110.1016/i.diagmicrobio.2010.07.021.

115. Wachino J, Yamane K, Shibayama K, Kurokawa H, Shibata N, Suzuki S, Doi Y, Kimura K, Ike Y, Arakawa Y. 2006. Novel plasmidmediated 16S rRNA methylase, RmtC, found in a Proteus mirabilis isolate demonstrating extraordinary high-level resistance against various aminoglycosides. Antimicrob Agents Chemother 50:178-184 http://dx.doi.org 110.1128/AAC.50.1.178-184.2006.

116. Yu YS, Zhou H, Yang Q, Chen YG, Li LJ. 2007. Widespread occurrence of aminoglycoside resistance due to ArmA methylase in imipenem-resistant Acinetobacter baumannii isolates in China. J Antimicrob Chemother 60:454-455 http://dx.doi.org/10.1093/jac/dkm208.

117. Galimand M, Sabtcheva S, Courvalin P, Lambert T. 2005. Worldwide disseminated armA aminoglycoside resistance methylase gene is borne by composite transposon Tn1548. Antimicrob Agents Chemother 49:2949-2953 http://dx.doi.org/10.1128/AAC.49.7.2949-2953.2005.

118. González-Zorn B, Teshager T, Casas M, Porrero MC, Moreno MA, Courvalin P, Domínguez L. 2005. armA and aminoglycoside resistance in Escherichia coli. Emerg Infect Dis 11:954-956 http://dx.doi.org/10.3201 leid1106.040553.

119. Chen L, Chen ZL, Liu JH, Zeng ZL, Ma JY, Jiang HX. 2007. Emergence of RmtB methylase-producing Escherichia coli and Enterobacter cloacae isolates from pigs in China. J Antimicrob Chemother 59: 880-885 http://dx.doi.org/10.1093/jac/dkm065.

120. Du XD, Wu CM, Liu HB, Li XS, Beier RC, Xiao F, Qin SS, Huang SY, Shen JZ. 2009. Plasmid-mediated ArmA and RmtB 16S rRNA methylases in Escherichia coli isolated from chickens. J Antimicrob Chemother 64:1328-1330 http://dx.doi.org/10.1093/jac/dkp354.

121. Liu BT, Liao XP, Yue L, Chen XY, Li L, Yang SS, Sun J, Zhang S, Liao SD, Liu YH. 2013. Prevalence of $\beta$-lactamase and 16S rRNA methylase genes among clinical Escherichia coli isolates carrying plasmidmediated quinolone resistance genes from animals. Microb Drug Resist 19:237-245 http://dx.doi.org/10.1089/mdr.2012.0179.

122. Yu T, He T, Yao H, Zhang JB, Li XN, Zhang RM, Wang GQ. 2015. Prevalence of $16 \mathrm{~S}$ rRNA methylase gene rmtB among Escherichia coli isolated from bovine mastitis in Ningxia, China. Foodborne Pathog Dis 12:770-777 http://dx.doi.org/10.1089/fpd.2015.1983.

123. Yang Y, Zhang A, Lei C, Wang H, Guan Z, Xu C, Liu B, Zhang D, Li Q, Jiang W, Pan Y, Yang C. 2015. Characteristics of plasmids coharboring $16 \mathrm{~S}$ rRNA methylases, CTX-M, and virulence factors in Escherichia coli and Klebsiella pneumoniae isolates from chickens in China. Foodborne Pathog Dis 12:873-880 http://dx.doi.org/10.1089/fpd.2015 .2025 .

124. Lupo A, Saras E, Madec JY, Haenni M. 2018. Emergence of $b l a_{\text {CTX- }}$ $\mathrm{M}-55$ associated with fos $A, r m t B$ and $m c r$ gene variants in Escherichia coli from various animal species in France. J Antimicrob Chemother 73:867872 http://dx.doi.org/10.1093/jac/dkx489.
125. Leigue L, Warth JF, Melo LC, Silva KC, Moura RA, Barbato L, Silva LC, Santos AC, Silva RM, Lincopan N. 2015. MDR ST2179-CTXM-15 Escherichia coli co-producing RmtD and $\mathrm{AAC}\left(6^{\prime}\right)-\mathrm{Ib}-\mathrm{cr}$ in a horse with extraintestinal infection, Brazil. J Antimicrob Chemother 70:12631265 .

126. Lee CS, Hu F, Rivera JI, Doi Y. 2014. Escherichia coli sequence type 354 coproducing CMY-2 cephalosporinase and RmtE 16 S rRNA methyltransferase. Antimicrob Agents Chemother 58:4246-4247 http://dx.doi .org/10.1128/AAC.02627-14.

127. Xia J, Sun J, Li L, Fang LX, Deng H, Yang RS, Li XP, Liao XP, Liu YH. 2015. First report of the IncI1/ST898 conjugative plasmid carrying rmtE2 16S rRNA methyltransferase gene in Escherichia coli. Antimicrob Agents Chemother 59:7921-7922 http://dx.doi.org/10.1128 IAAC.01235-15.

128. Zou W, Li C, Yang X, Wang Y, Cheng G, Zeng J, Zhang X, Chen Y, Cai R, Huang Q, Feng L, Wang H, Li D, Zhang G, Chen Y, Zhang Z, Zhang H. 2018. Frequency of antimicrobial resistance and integron gene cassettes in Escherichia coli isolated from giant pandas (Ailuropoda melanoleuca) in China. Microb Pathog 116:173-179 http://dx.doi.org /10.1016/j.micpath.2018.01.034.

129. Gutierrez B, Escudero JA, San Millan A, Hidalgo L, Carrilero L, Ovejero CM, Santos-Lopez A, Thomas-Lopez D, Gonzalez-Zorn B. 2012. Fitness cost and interference of Arm/Rmt aminoglycoside resistance with the RsmF housekeeping methyltransferases. Antimicrob Agents Chemother 56:2335-2341 http://dx.doi.org/10.1128/AAC.06066-11.

130. Lioy VS, Goussard S, Guerineau V, Yoon EJ, Courvalin P, Galimand M, Grillot-Courvalin C. 2014. Aminoglycoside resistance 16S rRNA methyltransferases block endogenous methylation, affect translation efficiency and fitness of the host. RNA 20:382-391 http://dx.doi.org/10.1261 /rna.042572.113.

131. Ramirez MS, Tolmasky ME. 2010. Aminoglycoside modifying enzymes. Drug Resist Updat 13:151-171 http://dx.doi.org/10.1016/j.drup .2010 .08 .003 .

132. Choi MJ, Lim SK, Nam HM, Kim AR, Jung SC, Kim MN. 2011. Apramycin and gentamicin resistances in indicator and clinical Escherichia coli isolates from farm animals in Korea. Foodborne Pathog Dis 8:119-123 http://dx.doi.org/10.1089/fpd.2010.0641.

133. Costa D, Poeta P, Sáenz Y, Vinué L, Coelho AC, Matos M, Rojo-Bezares B, Rodrigues J, Torres C. 2008. Mechanisms of antibiotic resistance in Escherichia coli isolates recovered from wild animals. Microb Drug Resist 14:71-77 http://dx.doi.org/10.1089/mdr.2008.0795.

134. Haldorsen BC, Simonsen GS, Sundsfjord A, Samuelsen O, Norwegian Study Group on Aminoglycoside Resistance. 2014. Increased prevalence of aminoglycoside resistance in clinical isolates of Escherichia coli and Klebsiella spp. in Norway is associated with the acquisition of AAC (3)-II and AAC(6')-Ib. Diagn Microbiol Infect Dis 78:66-69 http://dx.doi .org/10.1016/j.diagmicrobio.2013.10.001.

135. Medina A, Horcajo P, Jurado S, De la Fuente R, Ruiz-Santa-Quiteria JA, Domínguez-Bernal G, Orden JA. 2011. Phenotypic and genotypic characterization of antimicrobial resistance in enterohemorrhagic Escherichia coli and atypical enteropathogenic E. coli strains from ruminants. $J$ Vet Diagn Invest 23:91-95 http://dx.doi.org/10.1177/1040638711023 00114 .

136. Radhouani H, Poeta P, Gonçalves A, Pacheco R, Sargo R, Igrejas G. 2012. Wild birds as biological indicators of environmental pollution: antimicrobial resistance patterns of Escherichia coli and enterococci isolated from common buzzards (Buteo buteo). J Med Microbiol 61:837-843 http://dx.doi.org/10.1099/jmm.0.038364-0.

137. Radhouani H, Poeta P, Igrejas G, Gonçalves A, Vinué L, Torres C. 2009. Antimicrobial resistance and phylogenetic groups in isolates of Escherichia coli from seagulls at the Berlengas nature reserve. Vet Rec 165:138-142 http://dx.doi.org/10.1136/vr.165.5.138.

138. Rocha-Gracia RC, Cortés-Cortés G, Lozano-Zarain P, Bello F, Martínez-Laguna Y, Torres C. 2015. Faecal Escherichia coli isolates from 
healthy dogs harbour CTX-M-15 and CMY-2 $\beta$-lactamases. Vet J 203: 315-319 http://dx.doi.org/10.1016/j.tvil.2014.12.026.

139. Silva N, Igrejas G, Figueiredo N, Gonçalves A, Radhouani H, Rodrigues J, Poeta P. 2010. Molecular characterization of antimicrobial resistance in enterococci and Escherichia coli isolates from European wild rabbit (Oryctolagus cuniculus). Sci Total Environ 408:4871-4876 http://dx.doi.org/10.1016/j.scitotenv.2010.06.046.

140. Xiao Y, Hu Y. 2012. The major aminoglycoside-modifying enzyme AAC(3)-II found in Escherichia coli determines a significant disparity in its resistance to gentamicin and amikacin in China. Microb Drug Resist 18:42-46 http://dx.doi.org/10.1089/mdr.2010.0190.

141. Allen SE, Boerlin P, Janecko N, Lumsden JS, Barker IK, Pearl DL, Reid-Smith RJ, Jardine C. 2011. Antimicrobial resistance in generic Escherichia coli isolates from wild small mammals living in swine farm, residential, landfill, and natural environments in southern Ontario, Canada. Appl Environ Microbiol 77:882-888 http://dx.doi.org/10.1128 IAEM.01111-10.

142. Gonçalves A, Igrejas G, Radhouani H, Correia S, Pacheco R, Santos T, Monteiro R, Guerra A, Petrucci-Fonseca F, Brito F, Torres C, Poeta P. 2013. Antimicrobial resistance in faecal enterococci and Escherichia coli isolates recovered from Iberian wolf. Lett Appl Microbiol 56:268-274 http://dx.doi.org/10.1111/lam.12044.

143. Gonçalves A, Igrejas G, Radhouani H, Santos T, Monteiro R, Pacheco R, Alcaide E, Zorrilla I, Serra R, Torres C, Poeta P. 2013. Detection of antibiotic resistant enterococci and Escherichia coli in free range Iberian Lynx (Lynx pardinus). Sci Total Environ 456-457:115-119 http://dx.doi.org/10.1016/j.scitotenv.2013.03.073.

144. Marchant M, Vinué L, Torres C, Moreno MA. 2013. Change of integrons over time in Escherichia coli isolates recovered from healthy pigs and chickens. Vet Microbiol 163:124-132 http://dx.doi.org/10.1016 /j.vetmic.2012.12.011.

145. Marinho C, Igrejas G, Gonçalves A, Silva N, Santos T, Monteiro R, Gonçalves D, Rodrigues T, Poeta P. 2014. Azorean wild rabbits as reservoirs of antimicrobial resistant Escherichia coli. Anaerobe 30:116-119 http://dx.doi.org/10.1016/j.anaerobe.2014.09.009.

146. Radhouani H, Igrejas G, Gonçalves A, Pacheco R, Monteiro R, Sargo R, Brito F, Torres C, Poeta P. 2013. Antimicrobial resistance and virulence genes in Escherichia coli and enterococci from red foxes (Vulpes vulpes). Anaerobe 23:82-86 http://dx.doi.org/10.1016/j.anaerobe.2013.06.013.

147. Sacristán C, Esperón F, Herrera-León S, Iglesias I, Neves E, Nogal V, Muñoz MJ, de la Torre A. 2014. Virulence genes, antibiotic resistance and integrons in Escherichia coli strains isolated from synanthropic birds from Spain. Avian Pathol 43:172-175 http://dx.doi.org/10.1080/03079457.2014 .897683.

148. Santos T, Silva N, Igrejas G, Rodrigues P, Micael J, Rodrigues T, Resendes R, Gonçalves A, Marinho C, Gonçalves D, Cunha R, Poeta P. 2013. Dissemination of antibiotic resistant Enterococcus spp. and Escherichia coli from wild birds of Azores Archipelago. Anaerobe 24:25-31 http://dx.doi.org/10.1016/j.anaerobe.2013.09.004.

149. Karczmarczyk M, Abbott Y, Walsh C, Leonard N, Fanning S. 2011. Characterization of multidrug-resistant Escherichia coli isolates from animals presenting at a university veterinary hospital. Appl Environ Microbiol 77:7104-7112 http://dx.doi.org/10.1128/AEM.00599-11.

150. Shin SW, Byun JW, Jung M, Shin MK, Yoo HS. 2014. Antimicrobial resistance, virulence genes and PFGE-profiling of Escherichia coli isolates from South Korean cattle farms. J Microbiol 52:785-793 http://dx.doi.org /10.1007/s12275-014-4166-1.

151. Toszeghy M, Phillips N, Reeves H, Wu G, Teale C, Coldham N, Randall L. 2012. Molecular and phenotypic characterisation of extended spectrum $\beta$-lactamase CTX-M Escherichia coli from farm animals in Great Britain. Res Vet Sci 93:1142-1150 http://dx.doi.org/10.1016/j.rvsc .2012 .05 .001

152. Yamamoto S, Iwabuchi E, Hasegawa M, Esaki H, Muramatsu M, Hirayama N, Hirai K. 2013. Prevalence and molecular epidemiological characterization of antimicrobial-resistant Escherichia coli isolates from Japanese black beef cattle. J Food Prot 76:394-404 http://dx.doi.org 110.4315/0362-028X.JFP-12-273.

153. Adelowo OO, Fagade OE, Agersø Y. 2014. Antibiotic resistance and resistance genes in Escherichia coli from poultry farms, southwest Nigeria. J Infect Dev Ctries 8:1103-1112 http://dx.doi.org/10.3855/jidc .4222 .

154. Zhang FY, Huo SY, Li YR, Xie R, Wu XJ, Chen LG, Gao YH. 2014. A survey of the frequency of aminoglycoside antibiotic-resistant genotypes and phenotypes in Escherichia coli in broilers with septicaemia in Hebei, China. Br Poult Sci 55:305-310 http://dx.doi.org/10.1080/00071668 .2014.891096.

155. Gonçalves A, Torres C, Silva N, Carneiro C, Radhouani H, Coelho C, Araújo C, Rodrigues J, Vinué L, Somalo S, Poeta P, Igrejas G. 2010. Genetic characterization of extended-spectrum $\beta$-lactamases in Escherichia coli isolates of pigs from a Portuguese intensive swine farm. Foodborne Pathog Dis 7:1569-1573 http://dx.doi.org/10.1089/fpd.2010 .0598 .

156. Tang X, Tan C, Zhang X, Zhao Z, Xia X, Wu B, Guo A, Zhou R, Chen H. 2011. Antimicrobial resistances of extraintestinal pathogenic Escherichia coli isolates from swine in China. Microb Pathog 50:207-212 http://dx.doi.org/10.1016/j.micpath.2011.01.004.

157. Zhang WJ, Xu XR, Schwarz S, Wang XM, Dai L, Zheng HJ, Liu S. 2014. Characterization of the IncA/C plasmid pSCEC2 from Escherichia coli of swine origin that harbours the multiresistance gene $c f r$. J Antimicrob Chemother 69:385-389 http://dx.doi.org/10.1093/jac/dkt355.

158. Falagas ME, Vouloumanou EK, Samonis G, Vardakas KZ. 2016 Fosfomycin. Clin Microbiol Rev 29:321-347 http://dx.doi.org/10.1128 /CMR.00068-15

159. Pérez DS, Tapia MO, Soraci AL. 2014. Fosfomycin: uses and potentialities in veterinary medicine. Open Vet J 4:26-43.

160. Silver LL. 2017. Fosfomycin: mechanism and resistance. Cold Spring Harb Perspect Med 7:7 http://dx.doi.org/10.1101/cshperspect .a025262.

161. Wang X, Zhu Y, Hua X, Chen F, Wang C, Zhang Y, Liu S, Zhang W. 2018. F14:A-:B- and IncX4 Inc group $c$ fr-positive plasmids circulating in Escherichia coli of animal origin in Northeast China. Vet Microbiol 217:53-57 http://dx.doi.org/10.1016/j.vetmic.2018.02.003.

162. Wang XM, Dong Z, Schwarz S, Zhu Y, Hua X, Zhang Y, Liu S, Zhang WJ. 2017. Plasmids of diverse Inc groups disseminate the fosfomycin resistance gene fosA3 among Escherichia coli isolates from pigs, chickens, and dairy cows in Northeast China. Antimicrob Agents Chemother 61:e0859-e00817 http://dx.doi.org/10.1128/AAC.00859-17.

163. Hou J, Huang X, Deng Y, He L, Yang T, Zeng Z, Chen Z, Liu JH. 2012. Dissemination of the fosfomycin resistance gene fos $A 3$ with CTX M $\beta$-lactamase genes and $r m t B$ carried on IncFII plasmids among Escherichia coli isolates from pets in China. Antimicrob Agents Chemother 56:2135-2138 http://dx.doi.org/10.1128/AAC.05104-11.

164. Yao H, Wu D, Lei L, Shen Z, Wang Y, Liao K. 2016. The detection of fosfomycin resistance genes in Enterobacteriaceae from pets and their owners. Vet Microbiol 193:67-71 http://dx.doi.org/10.1016/j.vetmic 2016.07.019.

165. Xie M, Lin D, Chen K, Chan EW, Yao W, Chen S. 2016. Molecular characterization of Escherichia coli strains isolated from retail meat that harbor bla ${ }_{\mathrm{CTX}-\mathrm{M}}$ and fosA3 genes. Antimicrob Agents Chemother 60: 2450-2455 http://dx.doi.org/10.1128/AAC.03101-15.

166. He L, Partridge SR, Yang X, Hou J, Deng Y, Yao Q, Zeng Z, Chen Z, Liu JH. 2013. Complete nucleotide sequence of pHN7A8, an F33:A:B-type epidemic plasmid carrying $b l a_{\mathrm{CTX}-\mathrm{M}-65}$, fos $A 3$ and $r m t B$ from China. J Antimicrob Chemother 68:46-50 http://dx.doi.org/10.1093/jac Idks369.

167. Ho PL, Chan J, Lo WU, Law PY, Chow KH. 2013. Plasmid-mediated fosfomycin resistance in Escherichia coli isolated from pig. Vet Microbiol 162:964-967 http://dx.doi.org/10.1016/i.vetmic.2012.09.023. 
168. Sun H, Li S, Xie Z, Yang F, Sun Y, Zhu Y, Zhao X, Jiang S. 2012. A novel multidrug resistance plasmid isolated from an Escherichia coli strain resistant to aminoglycosides. J Antimicrob Chemother 67:1635$1638 \mathrm{http}: / / \mathrm{dx}$.doi.org/10.1093/jac/dks107.

169. Pan YS, Yuan L, Zong ZY, Liu JH, Wang LF, Hu GZ. 2014. A multidrug-resistance region containing bla $a_{\mathrm{CTX}-\mathrm{M}-65}$, fos $A 3$ and $r m t B$ on conjugative IncFII plasmids in Escherichia coli ST117 isolates from chicken. J Med Microbiol 63:485-488 http://dx.doi.org/10.1099/jmm.0 .070664-0.

170. Hou J, Yang X, Zeng Z, Lv L, Yang T, Lin D, Liu JH. 2013. Detection of the plasmid-encoded fosfomycin resistance gene fos $A 3$ in Escherichia coli of food-animal origin. J Antimicrob Chemother 68:766770 http://dx.doi.org/10.1093/jac/dks465.

171. Ho PL, Chan J, Lo WU, Law PY, Li Z, Lai EL, Chow KH. 2013. Dissemination of plasmid-mediated fosfomycin resistance fos $A 3$ among multidrug-resistant Escherichia coli from livestock and other animals. J Appl Microbiol 114:695-702 http://dx.doi.org/10.1111/jam.12099.

172. Tseng SP, Wang SF, Kuo CY, Huang JW, Hung WC, Ke GM, Lu PL. 2015. Characterization of fosfomycin resistant extended-spectrum $\beta$-lactamase-producing Escherichia coli isolates from human and pig in Taiwan. PLoS One 10:e0135864 http://dx.doi.org/10.1371/journal.pone .0135864 .

173. Grave K, Torren-Edo J, Muller A, Greko C, Moulin G, Mackay D, Group E, ESVAC Group. 2014. Variations in the sales and sales patterns of veterinary antimicrobial agents in 25 European countries. J Antimicrob Chemother 69:2284-2291 http://dx.doi.org/10.1093/jac/dku106.

174. Shin SW, Shin MK, Jung M, Belaynehe KM, Yoo HS. 2015. Prevalence of antimicrobial resistance and transfer of tetracycline resistance genes in Escherichia coli isolates from beef cattle. Appl Environ Microbiol 81:5560-5566 http://dx.doi.org/10.1128/AEM.01511-15.

175. Metzger SA, Hogan JS. 2013. Short communication: antimicrobial susceptibility and frequency of resistance genes in Escherichia coli isolated from bovine mastitis. J Dairy Sci 96:3044-3049 http://dx.doi.org/10.3168 ljds.2012-6402.

176. Srinivasan V, Gillespie BE, Lewis MJ, Nguyen LT, Headrick SI, Schukken YH, Oliver SP. 2007. Phenotypic and genotypic antimicrobial resistance patterns of Escherichia coli isolated from dairy cows with mastitis. Vet Microbiol 124:319-328 http://dx.doi.org/10.1016/j.vetmic 2007.04.040

177. Lanz R, Kuhnert P, Boerlin P. 2003. Antimicrobial resistance and resistance gene determinants in clinical Escherichia coli from different animal species in Switzerland. Vet Microbiol 91:73-84 http://dx.doi.org /10.1016/S0378-1135(02)00263-8.

178. Jurado-Rabadán S, de la Fuente R, Ruiz-Santa-Quiteria JA, Orden JA, de Vries LE, Agersø Y. 2014. Detection and linkage to mobile genetic elements of tetracycline resistance gene tet $(\mathrm{M})$ in Escherichia coli isolates from pigs. BMC Vet Res 10:155-162 http://dx.doi.org/10.1186/1746 -6148-10-155.

179. Hölzel CS, Harms KS, Bauer J, Bauer-Unkauf I, Hörmansdorfer S, Kämpf P, Mölle G, Oehme C, Preikschat P, Schwaiger K. 2012. Diversity of antimicrobial resistance genes and class-1-integrons in phylogenetically related porcine and human Escherichia coli. Vet Microbiol 160:403-412 http://dx.doi.org/10.1016/j.vetmic.2012.06.010.

180. Seifi S, Khoshbakht R. 2016. Prevalence of tetracycline resistance determinants in broiler isolated Escherichia coli in Iran. Br Poult Sci 57:729-733 http://dx.doi.org/10.1080/00071668.2016.1232478.

181. Costa D, Poeta P, Sáenz Y, Coelho AC, Matos M, Vinué L, Rodrigues J, Torres C. 2008. Prevalence of antimicrobial resistance and resistance genes in faecal Escherichia coli isolates recovered from healthy pets. Vet Microbiol 127:97-105 http://dx.doi.org/10.1016/j.vetmic.2007 .08 .004 .

182. Bryan A, Shapir N, Sadowsky MJ. 2004. Frequency and distribution of tetracycline resistance genes in genetically diverse, nonselected, and nonclinical Escherichia coli strains isolated from diverse human and ani- mal sources. Appl Environ Microbiol 70:2503-2507 http://dx.doi.org /10.1128/AEM.70.4.2503-2507.2004.

183. Allmeier H, Cresnar B, Greck M, Schmitt R. 1992. Complete nucleotide sequence of $\mathrm{Tn} 1721$ : gene organization and a novel gene product with features of a chemotaxis protein. Gene 111:11-20 http://dx.doi.org /10.1016/0378-1119(92)90597-I.

184. Chalmers R, Sewitz S, Lipkow K, Crellin P. 2000. Complete nucleotide sequence of Tn10. J Bacteriol 182:2970-2972 http://dx.doi.org /10.1128/JB.182.10.2970-2972.2000.

185. Siqueira AK, Michael GB, Domingos DF, Ferraz MM, Ribeiro MG, Schwarz S, Leite DS. 2016. Diversity of class 1 and 2 integrons detected in Escherichia coli isolates from diseased and apparently healthy dogs. Vet Microbiol 194:79-83 http://dx.doi.org/10.1016/j.vetmic.2016.05.005.

186. Huang SY, Zhu XQ, Wang Y, Liu HB, Dai L, He JK, Li BB, Wu CM, Shen JZ. 2012. Co-carriage of qnrS1, floR, and bla (СтX-M-14) on a multidrug-resistant plasmid in Escherichia coli isolated from pigs. Foodborne Pathog Dis 9:896-901 http://dx.doi.org/10.1089/fpd.2012 .1131.

187. Schwarz S, Kehrenberg C, Doublet B, Cloeckaert A. 2004. Molecular basis of bacterial resistance to chloramphenicol and florfenicol. FEMS Microbiol Rev 28:519-542 http://dx.doi.org/10.1016/j.femsre.2004.04 .001.

188. Wang XM, Liao XP, Liu SG, Zhang WJ, Jiang HX, Zhang MJ, Zhu HQ, Sun Y, Sun J, Li AX, Liu YH. 2011. Serotypes, virulence genes, and antimicrobial susceptibility of Escherichia coli isolates from pigs. Foodborne Pathog Dis 8:687-692 http://dx.doi.org/10.1089/fpd.2010 .0739 .

189. Travis RM, Gyles CL, Reid-Smith R, Poppe C, McEwen SA, Friendship R, Janecko N, Boerlin P. 2006. Chloramphenicol and kanamycin resistance among porcine Escherichia coli in Ontario. J Antimicrob Chemother 58:173-177 http://dx.doi.org/10.1093/jac/dkl207.

190. White DG, Hudson C, Maurer JJ, Ayers S, Zhao S, Lee MD, Bolton L, Foley T, Sherwood J. 2000. Characterization of chloramphenicol and florfenicol resistance in Escherichia coli associated with bovine diarrhea. J Clin Microbiol 38:4593-4598.

191. Guerra B, Junker E, Schroeter A, Malorny B, Lehmann S, Helmuth R. 2003. Phenotypic and genotypic characterization of antimicrobial resistance in German Escherichia coli isolates from cattle, swine and poultry. J Antimicrob Chemother 52:489-492 http://dx.doi.org/10.1093/jac /dkg362.

192. Awad A, Arafat N, Elhadidy M. 2016. Genetic elements associated with antimicrobial resistance among avian pathogenic Escherichia coli. Ann Clin Microbiol Antimicrob 15:59-67 http://dx.doi.org/10.1186 /s12941-016-0174-9.

193. Ahmed MO, Clegg PD, Williams NJ, Baptiste KE, Bennett M. 2010. Antimicrobial resistance in equine faecal Escherichia coli isolates from North West England. Ann Clin Microbiol Antimicrob 9:12-19 http://dx doi.org/10.1186/1476-0711-9-12.

194. Shaheen BW, Oyarzabal OA, Boothe DM. 2010. The role of class 1 and 2 integrons in mediating antimicrobial resistance among canine and feline clinical E. coli isolates from the US. Vet Microbiol 144:363-370 http://dx.doi.org/10.1016/j.vetmic.2010.01.018.

195. Derakhshandeh A, Eraghi V, Boroojeni AM, Niaki MA, Zare S, Naziri Z. 2018. Virulence factors, antibiotic resistance genes and genetic relatedness of commensal Escherichia coli isolates from dogs and their owners. Microb Pathog 116:241-245 http://dx.doi.org/10.1016/j.micpath .2018 .01 .041 .

196. Chang SK, Lo DY, Wei HW, Kuo HC. 2015. Antimicrobial resistance of Escherichia coli isolates from canine urinary tract infections. J Vet Med Sci 77:59-65 http://dx.doi.org/10.1292/jvms.13-0281.

197. Van TT, Chin J, Chapman T, Tran LT, Coloe PJ. 2008. Safety of raw meat and shellfish in Vietnam: an analysis of Escherichia coli isolations for antibiotic resistance and virulence genes. Int J Food Microbiol 124:217-223 http://dx.doi.org/10.1016/i.iifoodmicro.2008.03.029. 
198. Keyes K, Hudson C, Maurer JJ, Thayer S, White DG, Lee MD. 2000. Detection of florfenicol resistance genes in Escherichia coli isolated from sick chickens. Antimicrob Agents Chemother 44:421-424 http://dx.doi .org/10.1128/AAC.44.2.421-424.2000.

199. Bischoff KM, White DG, Hume ME, Poole TL, Nisbet DJ. 2005. The chloramphenicol resistance gene $\mathrm{cmlA}$ is disseminated on transferable plasmids that confer multiple-drug resistance in swine Escherichia coli. FEMS Microbiol Lett 243:285-291 http://dx.doi.org/10.1016/j.femsle 2004.12.017.

200. Blickwede M, Schwarz S. 2004. Molecular analysis of florfenicolresistant Escherichia coli isolates from pigs. J Antimicrob Chemother 53:58-64 http://dx.doi.org/10.1093/jac/dkh007.

201. Cloeckaert A, Baucheron S, Flaujac G, Schwarz S, Kehrenberg C, Martel JL, Chaslus-Dancla E. 2000. Plasmid-mediated florfenicol resistance encoded by the floR gene in Escherichia coli isolated from cattle. Antimicrob Agents Chemother 44:2858-2860 http://dx.doi.org/10.1128 IAAC.44.10.2858-2860.2000.

202. Shen J, Wang Y, Schwarz S. 2013. Presence and dissemination of the multiresistance gene $c f r$ in Gram-positive and Gram-negative bacteria. J Antimicrob Chemother 68:1697-1706 http://dx.doi.org/10.1093/jac /dkt092.

203. Wang Y, He T, Schwarz S, Zhou D, Shen Z, Wu C, Wang Y, Ma L, Zhang Q, Shen J. 2012. Detection of the staphylococcal multiresistance gene $c f r$ in Escherichia coli of domestic-animal origin. J Antimicrob Chemother 67:1094-1098 http://dx.doi.org/10.1093/jac/dks020.

204. Deng H, Sun J, Ma J, Li L, Fang LX, Zhang Q, Liu YH, Liao XP. 2014. Identification of the multi-resistance gene cfr in Escherichia coli isolates of animal origin. PLoS One 9:e102378 http://dx.doi.org/10.1371 /journal.pone.0102378.

205. Sun J, Deng H, Li L, Chen MY, Fang LX, Yang QE, Liu YH, Liao XP. 2015. Complete nucleotide sequence of $c f r$-carrying IncX4 plasmid pSD11 from Escherichia coli. Antimicrob Agents Chemother 59:738-741 http://dx.doi.org/10.1128/AAC.04388-14.

206. Zhang WJ, Wang XM, Dai L, Hua X, Dong Z, Schwarz S, Liu S. 2015. Novel conjugative plasmid from Escherichia coli of swine origin that coharbors the multiresistance gene $c f r$ and the extended-spectrum-

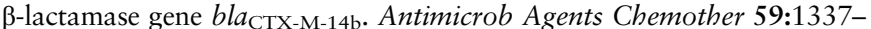
1340 http://dx.doi.org/10.1128/AAC.04631-14.

207. Zhang R, Sun B, Wang Y, Lei L, Schwarz S, Wu C. 2015. Characterization of a cfr-carrying plasmid from porcine Escherichia coli that closely resembles plasmid pEA3 from the plant pathogen Erwinia amylovora. Antimicrob Agents Chemother 60:658-661 http://dx.doi.org 110.1128/AAC.02114-15.

208. van Duijkeren E, Schink AK, Roberts MC, Wang Y, Schwarz S. 2018. Mechanisms of bacterial resistance to antimicrobial agents. Microbiol Spectr 6: http://dx.doi.org/10.1128/microbiolspec.ARBA-0019-2017. 209. Recchia GD, Hall RM. 1995. Gene cassettes: a new class of mobile element. Microbiology 141:3015-3027 http://dx.doi.org/10.1099 113500872-141-12-3015.

210. Kadlec K, Schwarz S. 2008. Analysis and distribution of class 1 and class 2 integrons and associated gene cassettes among Escherichia coli isolates from swine, horses, cats and dogs collected in the BfT-GermVet monitoring study. J Antimicrob Chemother 62:469-473 http://dx.doi.org /10.1093/jac/dkn233.

211. Bass L, Liebert CA, Lee MD, Summers AO, White DG, Thayer SG, Maurer JJ. 1999. Incidence and characterization of integrons, genetic elements mediating multiple-drug resistance, in avian Escherichia coli. Antimicrob Agents Chemother 43:2925-2929.

212. Waturangi DE, Suwanto A, Schwarz S, Erdelen W. 2003. Identification of class 1 integrons-associated gene cassettes in Escherichia coli isolated from Varanus spp. in Indonesia. J Antimicrob Chemother 51:175-177 http://dx.doi.org/10.1093/jac/dkf253.

213. Zhao S, White DG, Ge B, Ayers S, Friedman S, English L, Wagner D, Gaines S, Meng J. 2001. Identification and characterization of integron- mediated antibiotic resistance among Shiga toxin-producing Escherichia coli isolates. Appl Environ Microbiol 67:1558-1564 http://dx.doi.org 110.1128/AEM.67.4.1558-1564.2001.

214. Sunde M. 2005. Class I integron with a group II intron detected in an Escherichia coli strain from a free-range reindeer. Antimicrob Agents Chemother 49:2512-2514 http://dx.doi.org/10.1128/AAC.49.6.2512$\underline{2514.2005}$

215. Du X, Shen Z, Wu B, Xia S, Shen J. 2005. Characterization of class 1 integrons-mediated antibiotic resistance among calf pathogenic Escherichia coli. FEMS Microbiol Lett 245:295-298 http://dx.doi.org/10.1016 li.femsle.2005.03.021.

216. Wu S, Dalsgaard A, Hammerum AM, Porsbo LJ, Jensen LB. 2010. Prevalence and characterization of plasmids carrying sulfonamide resistance genes among Escherichia coli from pigs, pig carcasses and human. Acta Vet Scand 52:47 http://dx.doi.org/10.1186/1751-0147-52-47.

217. Sidjabat HE, Townsend KM, Hanson ND, Bell JM, Stokes HW, Gobius KS, Moss SM, Trott DJ. 2006. Identification of bla (CMY-7) and associated plasmid-mediated resistance genes in multidrug-resistant Escherichia coli isolated from dogs at a veterinary teaching hospital in Australia. J Antimicrob Chemother 57:840-848 http://dx.doi.org/10.1093 ljac/dkl057.

218. van Essen-Zandbergen A, Smith H, Veldman K, Mevius D. 2009. In vivo transfer of an incFIB plasmid harbouring a class 1 integron with gene cassettes $d$ frA1-aadA1. Vet Microbiol 137:402-407 http://dx.doi .org/10.1016/j.vetmic.2009.02.004.

219. Boerlin P, Travis R, Gyles CL, Reid-Smith R, Janecko N, Lim H, Nicholson V, McEwen SA, Friendship R, Archambault M. 2005. Antimicrobial resistance and virulence genes of Escherichia coli isolates from swine in Ontario. Appl Environ Microbiol 71:6753-6761 http://dx.do .org/10.1128/AEM.71.11.6753-6761.2005.

220. Kikuvi GM, Schwarz S, Ombui JN, Mitema ES, Kehrenberg C. 2007. Streptomycin and chloramphenicol resistance genes in Escherichia coli isolates from cattle, pigs, and chicken in Kenya. Microb Drug Resist 13:62-68 http://dx.doi.org/10.1089/mdr.2006.9998.

221. Ojo OE, Schwarz S, Michael GB. 2016. Detection and characterization of extended-spectrum $\beta$-lactamase-producing Escherichia coli from chicken production chains in Nigeria. Vet Microbiol 194:62-68 http://dx.doi.org/10.1016/j.vetmic.2016.04.022.

222. Schwaiger K, Bauer J, Hölzel CS. 2013. Selection and persistence of antimicrobial-resistant Escherichia coli including extended-spectrum $\beta$-lactamase producers in different poultry flocks on one chicken farm. Microb Drug Resist 19:498-506 http://dx.doi.org/10.1089/mdr.2012.0257. 223. Touzain F, Le Devendec L, de Boisséson C, Baron S, Jouy E, PerrinGuyomard A, Blanchard Y, Kempf I. 2018. Characterization of plasmids harboring bla $a_{\mathrm{CTX}-\mathrm{M}}$ and $b l a_{\mathrm{CMY}}$ genes in E. coli from French broilers. PLoS One 13:e0188768 http://dx.doi.org/10.1371/journal.pone.0188768. 224. Perreten V, Boerlin P. 2003. A new sulfonamide resistance gene (sul3) in Escherichia coli is widespread in the pig population of Switzerland. Antimicrob Agents Chemother 47:1169-1172 http://dx.doi.org/10.1128 /AAC.47.3.1169-1172.2003.

225. Liu J, Keelan P, Bennett PM, Enne VI. 2009. Characterization of a novel macrolide efflux gene, mef(B), found linked to sul3 in porcine Escherichia coli. J Antimicrob Chemother 63:423-426 http://dx.doi.org /10.1093/jac/dkn523.

226. Sunde M, Solheim H, Slettemeås JS. 2008. Genetic linkage between class 1 integrons with the $d f r A 12$-orfF-aadA2 cassette array and sul 3 in Escherichia coli. Vet Microbiol 130:422-425 http://dx.doi.org/10.1016 j.vetmic.2008.02.001

227. Pattishall KH, Acar J, Burchall JJ, Goldstein FW, Harvey RJ. 1977. Two distinct types of trimethoprim-resistant dihydrofolate reductase specified by R-plasmids of different compatibility groups. J Biol Chem 252:2319-2323

228. Reid CJ, Wyrsch ER, Roy Chowdhury P, Zingali T, Liu M, Darling AE, Chapman TA, Djordjevic SP. 2017. Porcine commensal Escherichia 
coli: a reservoir for class 1 integrons associated with IS26. Microb Genom 3:3 http://dx.doi.org/10.1099/mgen.0.000143.

229. Seputiené V, Povilonis J, Ruzauskas M, Pavilonis A, Suziedéliené E. 2010. Prevalence of trimethoprim resistance genes in Escherichia coli isolates of human and animal origin in Lithuania. J Med Microbiol 59: 315-322 http://dx.doi.org/10.1099/jmm.0.015008-0.

230. Delport TC, Harcourt RG, Beaumont LJ, Webster KN, Power ML. 2015. Molecular detection of antibiotic-resistance determinants inEscherichia coli isolated from the endangered Australian sea lion (Neophoca Cinerea). J Wildl Dis 51:555-563 http://dx.doi.org/10.7589 12014-08-200.

231. Ojo KK, Kehrenberg C, Schwarz S, Odelola HA. 2002. Identification of a complete $d f r A 14$ gene cassette integrated at a secondary site in a resistance plasmid of uropathogenic Escherichia coli from Nigeria. Antimicrob Agents Chemother 46:2054-2055 http://dx.doi.org/10.1128/AAC 46.6.2054-2055.2002.

232. Poirel L, Jayol A, Nordmann P. 2017. Polymyxins: antibacterial activity, susceptibility testing, and resistance mechanisms encoded by plasmids or chromosomes. Clin Microbiol Rev 30:557-596 http://dx.doi .org/10.1128/CMR.00064-16.

233. Rhouma M, Beaudry F, Thériault W, Letellier A. 2016. Colistin in pig production: chemistry, mechanism of antibacterial action, microbial resistance emergence, and One Health perspectives. Front Microbiol 7:1789 http://dx.doi.org/10.3389/fmicb.2016.01789.

234. Anonymous. 2016. European Medicines Agency. Updated advice on the use of colistin products in animals within the European Union: development of resistance and possible impact on human and animal health. EMA/CVMP/CHMP/231573.1-56.

235. Walsh TR, Wu Y. 2016. China bans colistin as a feed additive for animals. Lancet Infect Dis 16:1102-1103 http://dx.doi.org/10.1016 /S1473-3099(16)30329-2.

236. Quesada A, Porrero MC, Téllez S, Palomo G, García M, Domínguez L. 2015. Polymorphism of genes encoding PmrAB in colistin-resistant strains of Escherichia coli and Salmonella enterica isolated from poultry and swine. J Antimicrob Chemother 70:71-74 http://dx.doi.org/10.1093 /jac/dku320.

237. Delannoy S, Le Devendec L, Jouy E, Fach P, Drider D, Kempf I. 2017. Characterization of colistin-resistant Escherichia coli isolated from diseased pigs in France. Front Microbiol 8:2278 http://dx.doi.org/10.3389 /fmicb.2017.02278.

238. Liu YY, Wang Y, Walsh TR, Yi LX, Zhang R, Spencer J, Doi Y, Tian G, Dong B, Huang X, Yu LF, Gu D, Ren H, Chen X, Lv L, He D, Zhou H, Liang Z, Liu JH, Shen J. 2016. Emergence of plasmid-mediated colistin resistance mechanism MCR-1 in animals and human beings in China: a microbiological and molecular biological study. Lancet Infect Dis 16:161-168 http://dx.doi.org/10.1016/S1473-3099(15)00424-7.

239. Schwarz S, Johnson AP. 2016. Transferable resistance to colistin: a new but old threat. J Antimicrob Chemother 71:2066-2070 http://dx.doi .org/10.1093/jac/dkw274.

240. Falgenhauer L, Waezsada SE, Yao Y, Imirzalioglu C, Käsbohrer A, Roesler U, Michael GB, Schwarz S, Werner G, Kreienbrock L, Chakraborty T, RESET consortium. 2016. Colistin resistance gene $\mathrm{mcr}-1$ in extendedspectrum $\beta$-lactamase-producing and carbapenemase-producing Gramnegative bacteria in Germany. Lancet Infect Dis 16:282-283 http://dx.doi .org/10.1016/S1473-3099(16)00009-8.

241. Haenni M, Poirel L, Kieffer N, Châtre P, Saras E, Métayer V, Dumoulin R, Nordmann P, Madec JY. 2016. Co-occurrence of extended spectrum $\beta$ lactamase and MCR-1 encoding genes on plasmids. Lancet Infect Dis 16:281-282 http://dx.doi.org/10.1016/S1473-3099(16)00007-4. 242. Li R, Xie M, Zhang J, Yang Z, Liu L, Liu X, Zheng Z, Chan EW, Chen S. 2017. Genetic characterization of $m c r-1$-bearing plasmids to depict molecular mechanisms underlying dissemination of the colistin resistance determinant. J Antimicrob Chemother 72:393-401 http://dx.doi .org/10.1093/jac/dkw411.
243. Zurfluh K, Klumpp J, Nüesch-Inderbinen M, Stephan R. 2016. Full-length nucleotide sequences of $\mathrm{mcr}$-1-harboring plasmids isolated from extended-spectrum- $\beta$-lactamase-producing Escherichia coli isolates of different origins. Antimicrob Agents Chemother 60:5589-5591 http:// dx.doi.org/10.1128/AAC.00935-16.

244. Zurfuh K, Poirel L, Nordmann P, Nüesch-Inderbinen M, Hächler H, Stephan R. 2016. Occurrence of the plasmid-borne mcr-1 colistin resistance gene in extended-spectrum- $\beta$-lactamase-producing Enterobacteriaceae in river water and imported vegetable samples in Switzerland. Antimicrob Agents Chemother 60:2594-2595 http://dx.doi.org/10.1128 IAAC.00066-16.

245. Poirel L, Kieffer N, Nordmann P. 2017. In vitro study of ISApl1mediated mobilization of the colistin resistance gene mcr-1. Antimicrob Agents Chemother 61:61 http://dx.doi.org/10.1128/AAC.00127-17.

246. Yang YQ, Li YX, Song T, Yang YX, Jiang W, Zhang AY, Guo XY, Liu BH, Wang YX, Lei CW, Xiang R, Wang HN. 2017. Colistin resistance gene $m c r-1$ and its variant in Escherichia coli isolates from chickens in China. Antimicrob Agents Chemother 61:e01204-16.

247. Xavier BB, Lammens C, Ruhal R, Kumar-Singh S, Butaye P, Goossens H, Malhotra-Kumar S. 2016. Identification of a novel plasmidmediated colistin-resistance gene, $m c r-2$, in Escherichia coli, Belgium, June 2016. Euro Surveill 21:30280.

248. Zhang J, Chen L, Wang J, Yassin AK, Butaye P, Kelly P, Gong J, Guo W, Li J, Li M, Yang F, Feng Z, Jiang P, Song C, Wang Y, You J, Yang Y, Price S, Qi K, Kang Y, Wang C. 2018. Molecular detection of colistin resistance genes $(m c r-1, m c r-2$ and $m c r-3)$ in nasal/oropharyngeal and anal/cloacal swabs from pigs and poultry. Sci Rep 8:3705 http://dx.doi .org/10.1038/s41598-018-22084-4.

249. Yin W, Li H, Shen Y, Liu Z, Wang S, Shen Z, Zhang R, Walsh TR, Shen J, Wang Y. 2017. Novel plasmid-mediated colistin resistance gene mor-3 in Escherichia coli. MBio 8:e00543-17 http://dx.doi.org/10.1128/ mBio.00543-17.

250. Hernández M, Iglesias MR, Rodríguez-Lázaro D, Gallardo A, Quijada N, Miguela-Villoldo P, Campos MJ, Píriz S, López-Orozco G, de Frutos C, Sáez JL, Ugarte-Ruiz M, Domínguez L, Quesada A. 2017. Co-occurrence of colistin-resistance genes $\mathrm{mcr}-1$ and $\mathrm{mcr}$-3 among multidrug-resistant Escherichia coli isolated from cattle, Spain, September 2015. Euro Surveill 22:30586 http://dx.doi.org/10.2807/1560-7917.ES .2017.22.31.30586.

251. Haenni M, Beyrouthy R, Lupo A, Châtre P, Madec JY, Bonnet R. 2018. Epidemic spread of Escherichia coli ST744 isolates carrying $m c r-3$ and $b l a_{\text {СтХ-M-55 }}$ in cattle in France. J Antimicrob Chemother 73:533-536 http://dx.doi.org/10.1093/jac/dkx418.

252. Carattoli A, Villa L, Feudi C, Curcio L, Orsini S, Luppi A, Pezzotti G, Magistrali CF. 2017. Novel plasmid-mediated colistin resistance $m c r-4$ gene in Salmonella and Escherichia coli, Italy 2013, Spain and Belgium, 2015 to 2016. Euro Surveill 22:30589 http://dx.doi.org/10.2807/1560 -7917.ES.2017.22.31.30589.

253. Hammerl JA, Borowiak M, Schmoger S, Shamoun D, Grobbel M, Malorny B, Tenhagen BA, Käsbohrer A. 2018. $m c r-5$ and a novel $m c r-5.2$ variant in Escherichia coli isolates from food and food-producing animals, Germany, 2010 to 2017. J Antimicrob Chemother 73:1433-1435 http:// dx.doi.org/10.1093/jac/dky020.

254. Haenni M, Métayer V, Gay E, Madec JY. 2016. Increasing trends in $m c r-1$ prevalence among extended-spectrum- $\beta$-lactamase-producing Escherichia coli isolates from French calves despite decreasing exposure to colistin. Antimicrob Agents Chemother 60:6433-6434 http://dx.doi.org /10.1128/AAC.01147-16.

255. Shen Z, Wang Y, Shen Y, Shen J, Wu C. 2016. Early emergence of $m c r-1$ in Escherichia coli from food-producing animals. Lancet Infect Dis 16:293 http://dx.doi.org/10.1016/S1473-3099(16)00061-X.

256. Guenther S, Falgenhauer L, Semmler T, Imirzalioglu C, Chakraborty T, Roesler U, Roschanski N. 2017. Environmental emission of multiresistant Escherichia coli carrying the colistin resistance gene $\mathrm{mcr}$-1 from 
German swine farms. J Antimicrob Chemother 72:1289-1292 http://dx. doi.org/10.1093/jac/dkw585.

257. Hammerum AM, Larsen J, Andersen VD, Lester CH, Skovgaard Skytte TS, Hansen F, Olsen SS, Mordhorst H, Skov RL, Aarestrup FM, Agersø Y. 2014. Characterization of extended-spectrum $\beta$-lactamase (ESBL)-producing Escherichia coli obtained from Danish pigs, pig farmers and their families from farms with high or no consumption of third- or fourth-generation cephalosporins. J Antimicrob Chemother 69:26502657 http://dx.doi.org/10.1093/jac/dku180.

258. Börjesson S, Bengtsson B, Jernberg C, Englund S. 2013. Spread of extended-spectrum $\beta$-lactamase producing Escherichia coli isolates in Swedish broilers mediated by an incl plasmid carrying bla(CTX-M-1). Acta Vet Scand 55:3 http://dx.doi.org/10.1186/1751-0147-55-3.

259. Randall LP, Clouting C, Horton RA, Coldham NG, Wu G, CliftonHadley FA, Davies RH, Teale CJ. 2011. Prevalence of Escherichia coli carrying extended-spectrum $\beta$-lactamases (CTX-M and TEM-52) from broiler chickens and turkeys in Great Britain between 2006 and 2009. J Antimicrob Chemother 66:86-95 http://dx.doi.org/10.1093/jac/dkq396. 260. Endimiani A, Rossano A, Kunz D, Overesch G, Perreten V. 2012. First countrywide survey of third-generation cephalosporin-resistant Escherichia coli from broilers, swine, and cattle in Switzerland. Diagn Microbiol Infect Dis 73:31-38 http://dx.doi.org/10.1016/j.diagmicrobio .2012 .01 .004

261. Liu X, Thungrat K, Boothe DM. 2016. Occurrence of OXA-48 carbapenemase and other $\beta$-lactamase genes in ESBL-producing multidrug resistant Escherichia coli from dogs and cats in the United States, 20092013. Front Microbiol 7:1057 http://dx.doi.org/10.3389/fmicb.2016 .01057.

262. Liao XP, Xia J, Yang L, Li L, Sun J, Liu YH, Jiang HX. 2015. Characterization of CTX-M-14-producing Escherichia coli from foodproducing animals. Front Microbiol 6:1136 http://dx.doi.org/10.3389 /fmicb.2015.01136.

263. Falgenhauer L, Imirzalioglu C, Ghosh H, Gwozdzinski K, Schmiedel J, Gentil K, Bauerfeind R, Kämpfer P, Seifert H, Michael GB, Schwarz S, Pfeifer Y, Werner G, Pietsch M, Roesler U, Guerra B, Fischer J, Sharp H, Käsbohrer A, Goesmann A, Hille K, Kreienbrock L, Chakraborty T. 2016. Circulation of clonal populations of fluoroquinolone-resistant CTX-M-15-producing Escherichia coli ST410 in humans and animals in Germany. Int J Antimicrob Agents 47:457-465 http://dx.doi.org/10.1016 /j.ijantimicag.2016.03.019.

264. Ewers C, Grobbel M, Stamm I, Kopp PA, Diehl I, Semmler T, Fruth A, Beutlich J, Guerra B, Wieler LH, Guenther S. 2010. Emergence of human pandemic O25:H4-ST131 CTX-M-15 extended-spectrum- $\beta$ lactamase-producing Escherichia coli among companion animals. J Antimicrob Chemother 65:651-660 http://dx.doi.org/10.1093/jac/dkq004.

265. Schill F, Abdulmawjood A, Klein G, Reich F. 2017. Prevalence and characterization of extended-spectrum $\beta$-lactamase (ESBL) and AmpC $\beta$-lactamase producing Enterobacteriaceae in fresh pork meat at processing level in Germany. Int J Food Microbiol 257:58-66 http://dx .doi.org/10.1016/j.ijfoodmicro.2017.06.010.

266. Alcalá L, Alonso CA, Simón C, González-Esteban C, Orós J, Rezusta A, Ortega C, Torres C. 2016. Wild birds, frequent carriers of extendedspectrum $\beta$-lactamase (ESBL) producing Escherichia coli of CTX-M and SHV-12 types. Microb Ecol 72:861-869 http://dx.doi.org/10.1007 /s00248-015-0718-0.

267. Jones-Dias D, Manageiro V, Martins AP, Ferreira E, Caniça M. 2016. New class 2 integron In2-4 among IncI1-positive Escherichia coli isolates carrying ESBL and PMA $\beta$ genes from food animals in Portugal. Foodborne Pathog Dis 13:36-39 http://dx.doi.org/10.1089/fpd.2015 .1972 .

268. Vogt D, Overesch G, Endimiani A, Collaud A, Thomann A, Perreten V. 2014. Occurrence and genetic characteristics of third-generation cephalosporin-resistant Escherichia coli in Swiss retail meat. Microb Drug Resist 20:485-494 http://dx.doi.org/10.1089/mdr.2013.0210.
269. Park YS, Adams-Haduch JM, Rivera JI, Curry SR, Harrison LH, Doi Y. 2012. Escherichia coli producing CMY-2 $\beta$-lactamase in retail chicken, Pittsburgh, Pennsylvania, USA. Emerg Infect Dis 18:515-516 http://dx.doi.org/10.3201/eid1803.111434.

270. Cunha MP, Lincopan N, Cerdeira L, Esposito F, Dropa M, Franco LS, Moreno AM, Knobl T. 2017. Coexistence of CTX-M-2, CTX-M-55, CMY-2, FosA3, and QnrB19 in extraintestinal pathogenic Escherichia coli from poultry in Brazil. Antimicrob Agents Chemother 61:e2474-16 http://dx.doi.org/10.1128/AAC.02474-16.

271. Guo YF, Zhang WH, Ren SQ, Yang L, Lü DH, Zeng ZL, Liu YH, Jiang HX. 2014. IncA/C plasmid-mediated spread of CMY-2 in multidrug-resistant Escherichia coli from food animals in China. PLoS One 9: e96738 http://dx.doi.org/10.1371/journal.pone.0096738.

272. Ohnishi M, Okatani AT, Esaki H, Harada K, Sawada T, Murakami M, Marumo K, Kato Y, Sato R, Shimura K, Hatanaka N, Takahashi T. 2013. Herd prevalence of Enterobacteriaceae producing CTX-M-type and CMY-2 $\beta$-lactamases among Japanese dairy farms. J Appl Microbiol 115:282-289 http://dx.doi.org/10.1111/jam.12211.

273. Sato T, Yokota S, Okubo T, Usui M, Fujii N, Tamura Y. 2014. Phylogenetic association of fluoroquinolone and cephalosporin resistance of D-O1-ST648 Escherichia coli carrying bla $a_{\mathrm{CMY}-2}$ from faecal samples of dogs in Japan. J Med Microbiol 63:263-270 http://dx.doi.org/10.1099 jimm.0.054676-0.

274. Maamar E, Hammami S, Alonso CA, Dakhli N, Abbassi MS, Ferjani S, Hamzaoui Z, Saidani M, Torres C, Boutiba-Ben Boubaker I. 2016. High prevalence of extended-spectrum and plasmidic AmpC $\beta$-lactamaseproducing Escherichia coli from poultry in Tunisia. Int J Food Microbiol 231:69-75 http://dx.doi.org/10.1016/j.ijfoodmicro.2016.05.001.

275. Cui L, Lei L, Lv Y, Zhang R, Liu X, Li M, Zhang F, Wang Y. 2017. bla $_{\mathrm{NDM}-1}$-producing multidrug-resistant Escherichia coli isolated from a companion dog in China. J Glob Antimicrob Resist 13:24-27 http://dx .doi.org/10.1016/j.jgar.2017.10.021.

276. Lin D, Xie M, Li R, Chen K, Chan EW, Chen S. 2016. IncFII conjugative plasmid-mediated transmission of $b l a_{\mathrm{NDM}-1}$ elements among animal-borne Escherichia coli strains. Antimicrob Agents Chemother 61: e02285-16 http://dx.doi.org/10.1128/AAC.02285-16.

277. Kong LH, Lei CW, Ma SZ, Jiang W, Liu BH, Wang YX, Guan R, Men S, Yuan QW, Cheng GY, Zhou WC, Wang HN. 2017. Various sequence types of Escherichia coli isolates coharboring bla $a_{\mathrm{NDM}-5}$ and mcr-1 genes from a commercial swine farm in China. Antimicrob Agents Chemother 61:e02167-16 http://dx.doi.org/10.1128/AAC.02167-16.

278. Purkait D, Ahuja A, Bhattacharjee U, Singha A, Rhetso K, Dey TK, Das S, Sanjukta RK, Puro K, Shakuntala I, Sen A, Banerjee A, Sharma I, Bhatta RS, Mawlong M, Guha C, Pradhan NR, Ghatak S. 2016. Molecular characterization and computational modelling of New Delhi metallo- $\beta$-lactamase- 5 from an Escherichia coli isolate (KOEC3) of bovine origin. Indian J Microbiol 56:182-189 http://dx.doi.org/10.1007/s12088 -016-0569-5.

279. Yaici L, Haenni M, Saras E, Boudehouche W, Touati A, Madec JY.

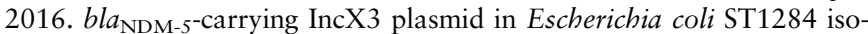
lated from raw milk collected in a dairy farm in Algeria. J Antimicrob Chemother 71:2671-2672 http://dx.doi.org/10.1093/jac/dkw160.

280. Roschanski N, Friese A, von Salviati-Claudius C, Hering J, Kaesbohrer A, Kreienbrock L, Roesler U. 2017. Prevalence of carbapenemase producing Enterobacteriaceae isolated from German pigfattening farms during the years 2011-2013. Vet Microbiol 200:124-129 http://dx.doi.org/10.1016/j.vetmic.2015.11.030.

281. Roschanski N, Guenther S, Vu TTT, Fischer J, Semmler T, Huehn S, Alter T, Roesler U. 2017. VIM-1 carbapenemase-producing Escherichia coli isolated from retail seafood, Germany 2016. Euro Surveill 22:17-00032 http://dx.doi.org/10.2807/1560-7917.ES.2017.22.43.17$\underline{00032 .}$

282. Unger F, Eisenberg T, Prenger-Berninghoff E, Leidner U, Ludwig ML, Rothe M, Semmler T, Ewers C. 2017. Imported reptiles as a risk 
factor for the global distribution of Escherichia coli harbouring the colistin resistance gene mcr-1. Int J Antimicrob Agents 49:122-123 http://dx.doi .org/10.1016/j.ijantimicag.2016.10.007.

283. Lim SK, Kang HY, Lee K, Moon DC, Lee HS, Jung SC. 2016. First detection of the $m c r-1$ gene in Escherichia coli isolated from livestock between 2013 and 2015 in South Korea. Antimicrob Agents Chemother 60:6991-6993 http://dx.doi.org/10.1128/AAC.01472-16.

284. Meinersmann RJ, Ladely SR, Plumblee JR, Cook KL, Thacker E. 2017. Prevalence of $m c r-1$ in the cecal contents of food animals in the United States. Antimicrob Agents Chemother 61:e2244-16 http://dx.doi. org/10.1128/AAC.02244-16.

285. Delgado-Blas JF, Ovejero CM, Abadia-Patiño L, Gonzalez-Zorn B. 2016. Coexistence of $m c r-1$ and bla $\mathrm{NDM}_{-1}$ in Escherichia coli from
Venezuela. Antimicrob Agents Chemother 60:6356-6358 http://dx.doi. org/10.1128/AAC.01319-16.

286. Sellera FP, Fernandes MR, Sartori L, Carvalho MP, Esposito F, Nascimento CL, Dutra GH, Mamizuka EM, Pérez-Chaparro PJ, McCulloch JA, Lincopan N. 2017. Escherichia coli carrying IncX4 plasmid-mediated $m c r-1$ and $b l a_{\text {СтХ-м }}$ genes in infected migratory Magellanic penguins (Spheniscus magellanicus). J Antimicrob Chemother 72:1255-1256 http:// dx.doi.org/10.1093/jac/dkw543.

287. Sellera FP, Fernandes MR, Ruiz R, Falleiros ACM, Rodrigues FP, Cerdeira L, Lincopan N. 2018. Identification of KPC-2-producing Escherichia coli in a companion animal: a new challenge for veterinary clinicians. J Antimicrob Chemother [Epub ahead of print] http://dx.doi. org/10.1093/jac/dky173. 